\title{
Immersion freezing of water and aqueous ammonium sulfate droplets initiated by humic-like substances as a function of water activity
}

\author{
Y. J. Rigg ${ }^{1, *}$, P. A. Alpert ${ }^{1, *}$, and D. A. Knopf ${ }^{1}$ \\ ${ }^{1}$ Institute for Terrestrial and Planetary Atmospheres/School of Marine and Atmospheric Sciences, Stony Brook University, \\ Stony Brook, New York, USA \\ *These authors contributed equally to this work.
}

Correspondence to: D. A. Knopf (daniel.knopf@stonybrook.edu)

Received: 1 February 2013 - Published in Atmos. Chem. Phys. Discuss.: 20 February 2013

Revised: 10 June 2013 - Accepted: 11 June 2013 - Published: 12 July 2013

\begin{abstract}
Immersion freezing of water and aqueous $\left(\mathrm{NH}_{4}\right)_{2} \mathrm{SO}_{4}$ droplets containing leonardite (LEO) and $\mathrm{Pa}-$ hokee peat (PP) serving as surrogates for humic-like substances (HULIS) has been investigated. Organic aerosol containing HULIS are ubiquitous in the atmosphere; however, their potential for ice cloud formation is uncertain. Immersion freezing has been studied for temperatures as low as $215 \mathrm{~K}$ and solution water activity, $a_{\mathrm{w}}$, from 0.85 to 1.0 . The freezing temperatures of water and aqueous solution droplets containing LEO and PP are 5-15 K warmer than homogeneous ice nucleation temperatures. Heterogeneous freezing temperatures can be represented by a horizontal shift of the ice melting curve as a function of solution $a_{\mathrm{w}}$ by $\Delta a_{\mathrm{w}}=0.2703$ and 0.2466 , respectively. Corresponding hetrogeneous ice nucleation rate coefficients, $J_{\text {het }}$, are $(9.6 \pm 2.5) \times 10^{4}$ and $(5.4 \pm 1.4) \times 10^{4} \mathrm{~cm}^{-2} \mathrm{~s}^{-1}$ for LEO and PP containing droplets, respectively, and remain constant along freezing curves characterized by $\Delta a_{\mathrm{w}}$. Consequently predictions of freezing temperatures and kinetics can be made without knowledge of the solute type when relative humidity and ice nuclei (IN) surface areas are known. The acquired ice nucleation data are applied to evaluate different approaches to fit and reproduce experimentally derived frozen fractions. In addition, we apply a basic formulation of classical nucleation theory $(\alpha(T)$-model) to calculate contact angles and frozen fractions. Contact angles calculated for each ice nucleus as a function of temperature, $\alpha(T)$-model, reproduce exactly experimentally derived frozen fractions without involving free-fit parameters. However, assigning the
\end{abstract}

IN a single contact angle for the entire population (single- $\alpha$ model) is not suited to represent the frozen fractions. Application of $\alpha$-PDF, active sites, and deterministic model approaches to measured frozen fractions yield similar good representations. Furthermore, when using a single parameterization of $\alpha$-PDF or active sites distribution to fit all individual $a_{\mathrm{w}}$ immersion freezing data simultaneously, frozen fraction curves are not reproduced. This implies that these fitting formulations cannot be applied to immersion freezing of aqueous solutions, and suggests that derived fit parameters do not represent independent particle properties. Thus, from fitting frozen fractions only, the underlying ice nucleation mechanism and nature of the ice nucleating sites cannot be inferred. In contrast to using fitted functions obtained to represent experimental conditions only, we suggest to use experimentally derived $J_{\text {het }}$ as a function of temperature and $a_{\mathrm{w}}$ that can be applied to conditions outside of those probed in laboratory. This is because $J_{\text {het }}(T)$ is independent of time and IN surface areas in contrast to the fit parameters obtained by representation of experimentally derived frozen fractions.

\section{Introduction}

Atmospheric aerosol particles serving as ice nuclei (IN) can affect the global radiation budget through altering the radiative properties of existing clouds and formation of ice clouds (Baker, 1997; Forster et al., 2007; Baker and Peter, 2008). Ice particles interact with incoming solar and outgoing terrestrial 
radiation through absorption and scattering processes (Chen et al., 2000). Cirrus clouds can account for up to $30 \%$ of total cloud coverage (Wylie et al., 2005) and their impact on the radiative forcing is estimated to have a predominantly warming effect (Chen et al., 2000). Prediction of the atmospheric ice production is challenging since ice particles can form by homogeneous or heterogeneous nucleation (Pruppacher and Klett, 1997). Homogenous ice nucleation refers to ice formation from a supercooled water or aqueous solution droplet as opposed to heterogeneous ice nucleation in which ice formation is initiated from a pre-existing substrate acting as an ice nucleus (Pruppacher and Klett, 1997).

Heterogeneous ice nucleation occurs at warmer temperatures and lower supersaturation with respect to ice than homogeneous ice nucleation (Pruppacher and Klett, 1997). Heterogeneous ice nucleation pathways, also referred to as modes, are as follows: deposition nucleation (the ice forms on the ice nucleus from supersaturated water vapor), immersion freezing (the ice forms on the ice nucleus immersed in a supercooled aqueous droplet), condensation freezing (ice forms after water vapor condenses onto the ice nucleus at supercooled temperatures), and contact freezing (ice formation is induced by collision of supercooled droplets with an ice nucleus) (Pruppacher and Klett, 1997). Ice crystal concentrations in cirrus clouds impacted by heterogeneous ice nucleation are ill defined and remain largely uncertain (Cantrell and Heymsfield, 2005; Forster et al., 2007). Field campaigns in addition to cloud models indicate that immersion freezing can occur under cirrus conditions (Heymsfield et al., 1998; DeMott et al., 1998; Seifert et al., 2003) and that immersion and condensation freezing can be important ice nucleation pathways within mixed-phase clouds in which supercooled water droplets and ice particles coexist (Rogers et al., 2001; DeMott et al., 2003; Verlinde et al., 2007; Prenni et al., 2009). Cirrus ice crystal residue analysis and cloud system resolving model studies also indicate that cirrus clouds can either form or are influenced by heterogeneous ice nucleation (Chen et al., 1998; Lohmann et al., 2001; DeMott et al., 2003; Kärcher and Lohmann, 2003; Cziczo et al., 2004; Lohmann et al., 2004; Prenni et al., 2009).

Field measurements have confirmed the presence of organic particulate matter at altitudes in which temperatures favor ice formation (Murphy et al., 1998, 2007; Jost et al., 2004; Froyd et al., 2010). Biomass burning plumes are a large source of both inorganic and organic particles that can reach the upper troposphere/lower stratosphere (Fromm et al., 2010; Hudson et al., 2004; Murphy et al., 2007). Anthropogenically emitted organic-containing particles have been shown to possess the potential to act as efficient IN at mixedphase and cirrus cloud formation conditions (Knopf et al., 2010; Wang and Knopf, 2011; Wang et al., 2012a,b; Baustian et al., 2012). Humic-like substances (HULIS) represent multiple organic compounds frequently encountered in atmospheric aerosol that can consist of both water soluble and insoluble species (Graber and Rudich, 2006). Biomass burn- ing is among the sources for atmospheric HULIS (Mukai and Ambe, 1986; Mayol-Bracero et al., 2002; Lukacs et al., 2007; Pio et al., 2008; Lin et al., 2010; Konovalov et al., 2012). Previous studies have indicated that particulate HULIS likely can be associated with ammonium sulfate $\left(\left(\mathrm{NH}_{4}\right)_{2} \mathrm{SO}_{4}\right)$ (Chan and Chan, 2003; Iinuma et al., 2007; Schmidl et al., 2008) and that HULIS surrogates such as Suwannee River standard fulvic acid and leonardite (LEO) can act as efficient deposition IN (Kanji et al., 2008; Wang and Knopf, 2011). Pahokee peat (PP) serving also as a HULIS surrogate has been investigated as potential IN in contact with the surface of a water drop and as immersion IN (Fornea et al., 2009). However, immersion freezing temperatures and corresponding ice nucleation kinetics of HULIS surrogates have neither been investigated as a function of solution water activity, $a_{\mathrm{w}}$, nor applying micrometer-sized aqueous solution droplets.

Here we address the question of how the presence of insoluble and partially soluble organic material affects ice nucleation from aqueous inorganic solution droplets with different $a_{\mathrm{w}}$. If heterogeneous ice nucleation does not occur, ice formation can commence from concentrated aqueous solutions via homogeneous ice nucleation and can be described by $a_{\mathrm{w}}$ and $T$, independent of the type of solute (Koop et al., 2000; Knopf and Lopez, 2009; Knopf and Rigg, 2011). Previous studies suggest that the $a_{\mathrm{w}}$-based description of homogeneous ice nucleation can also be applied to predict immersion freezing temperatures (Zobrist et al., 2008; Koop and Zobrist, 2009; Alpert et al., 2011a,b; Knopf et al., 2011). Kärcher and Lohmann parameterized immersion freezing by scaling the $a_{\mathrm{w}}$-based homogeneous ice nucleation theory (Kärcher and Lohmann, 2003). Only one study so far has derived freezing temperatures and heterogeneous ice nucleation rate coefficients applying the $a_{\mathrm{w}}$-based description (Knopf and Forrester, 2011), thus linking thermodynamic data with kinetic information similar to the $a_{\mathrm{w}}$-based description of homogeneous ice nucleation (Koop et al., 2000). In this study we investigate immersion freezing with respect to temperature and nucleation kinetics from micrometer-sized water and aqueous $\left(\mathrm{NH}_{4}\right)_{2} \mathrm{SO}_{4}$ droplets, representing slightly larger droplets than observed in the atmosphere (Sassen and Dodd, 1988; Heymsfield et al., 1998; Ansmann et al., 2008), containing PP and LEO particles acting as IN for $a_{\mathrm{w}}$ of $0.85-1.0$ and temperatures from 273 to $215 \mathrm{~K}$.

Previous literature has offered multiple ways of parameterizing and reproducing experimental immersion freezing data (Vali, 1971; Pruppacher and Klett, 1997; Zobrist et al., 2007; Marcolli et al., 2007; Lüönd et al., 2010; Alpert et al., 2011b). The reason for this stems from a lack of consensus as to whether ice nucleation is time dependent, for example, or if individual particles in an IN population possess the same ice nucleation efficiency. These parameterizations mainly rely on a statistical representation, i.e., using a fit, of the experimentally derived frozen fractions of droplets. Our freezing data are analyzed following the various approaches for the purpose of intercomparison and establishing their usefulness 
in assessing the underlying processes that govern ice nucleation. We first introduce a formulation for heterogeneous ice nucleation founded in classical nucleation theory, but that is independent of the frozen fraction. We assign each ice nucleus active at one specific ice nucleating temperature one contact angle, $\alpha(\alpha(T)$-model) (Pruppacher and Klett, 1997; Zobrist et al., 2007; Wang and Knopf, 2011; Alpert et al., 2011a,b; Knopf and Forrester, 2011). Second, a single contact angle, $\alpha$ over similar IN (single- $\alpha$ model, Marcolli et al., 2007; Lüönd et al., 2010), is applied. Third, a distribution of $\alpha$ over similar IN ( $\alpha$-PDF model, Marcolli et al., 2007; Lüönd et al., 2010) is assumed. Fourth, it is assumed that ice nucleation is initiated by active sites of different qualities (active sites model, Marcolli et al., 2007). Lastly, it is assumed that ice nucleation is only dependent on temperature (deterministic model, Vali, 1971). For the first time, these different heterogeneous ice nucleation descriptions are applied for immersion freezing data spanning a wide range of solution $a_{\mathrm{w}}$.

\section{Experimental}

\subsection{Droplet sample preparation}

Aqueous $\left(\mathrm{NH}_{4}\right)_{2} \mathrm{SO}_{4}$ solutions containing PP and LEO were prepared for generation of micrometer-sized droplets. These aqueous suspension compositions are given in Table 1. PP and LEO were first crushed using a mortar and pestle. Subsequently, the finely crushed and weighted material was immersed in a known amount of water, sonicated for $30 \mathrm{~min}$, and manually agitated roughly every $10 \mathrm{~min}$. Humic acid solubility is dependent on humic acid type and solution $\mathrm{pH}$ (Graber and Rudich, 2006). PP exhibited a brownish hue within minutes of being sonicated, indicating potential partial dissolution in water and aqueous $\left(\mathrm{NH}_{4}\right)_{2} \mathrm{SO}_{4}$ solutions that may include break up of particulate aggregates. LEO particles accumulated on top of the solutions when not agitated. The well mixed suspensions were then filtered through a $5 \mu \mathrm{m}$ filter. A significant amount of LEO particles, when placed in water, aggregated to form a large mass, which remained behind after filtering. From weighing the organic particle residues on the filter, we determined that about $75 \%$ of PP and LEO mass was filtered out. Lastly, a known quantity of $\left(\mathrm{NH}_{4}\right)_{2} \mathrm{SO}_{4}$ was added to the suspension, resulting in an aqueous solution with known PP or LEO and $\left(\mathrm{NH}_{4}\right)_{2} \mathrm{SO}_{4}$ content as given in Table 1. Prior to application for droplet generation, the aqueous suspensions were sonicated for an additional hour.

A piezo-electric single-droplet dispenser was employed to create single droplets containing LEO and PP on demand (Alpert et al., 2011a,b; Knopf and Rigg, 2011). For each sample 30-60 droplets were placed on a hydrophobic coated glass plate (Knopf and Lopez, 2009; Knopf and Rigg, 2011). The sample was introduced into an aerosol conditioning cell (ACC) that allows droplet exposure to controlled relative
Table 1. Composition of Pahokee peat (PP) and leonardite (LEO) containing aqueous ammonium sulfate droplets employed in ice nucleation experiments.

\begin{tabular}{lll}
\hline Component & $\begin{array}{l}\mathrm{PP} /\left(\mathrm{NH}_{4}\right)_{2} \mathrm{SO}_{4} / \\
\mathrm{H}_{2} \mathrm{O} / \mathrm{wt} \%\end{array}$ & $\begin{array}{l}\mathrm{LEO} /\left(\mathrm{NH}_{4}\right)_{2} \mathrm{SO}_{4} / \\
\mathrm{H}_{2} \mathrm{O} / \mathrm{wt} \%\end{array}$ \\
\hline Pahokee peat & 0.02 & - \\
Leonardite & - & 0.02 \\
$\mathrm{H}_{2} \mathrm{O}$ & 93.95 & 93.95 \\
\hline$\left(\mathrm{NH}_{4}\right)_{2} \mathrm{SO}_{4}$ & 6.03 & 6.03 \\
\hline
\end{tabular}

humidity (RH), as outlined in detail in our previous studies (Knopf and Lopez, 2009; Knopf and Rigg, 2011; Alpert et al., 2011a,b). In short, this is achieved by flowing humidified $\mathrm{N}_{2}$ gas with known dew point temperature, $T_{\mathrm{d}}$, as determined by a chilled mirror hygrometer, above the droplets. The uncertainty of $T_{\mathrm{d}}$ is $< \pm 0.15 \mathrm{~K}$. From $T_{\mathrm{d}}$ and the droplet temperature, $T_{\text {drop }}, \mathrm{RH}=\frac{p_{\mathrm{H}_{2} \mathrm{O}}\left(T_{\mathrm{d}}\right)}{p_{\mathrm{H}_{2} \mathrm{O}}^{0}\left(T_{\text {drop }}\right)}$ can be derived (Murphy and Koop, 2005). The uncertainty in $T_{\text {drop }}$ is $\pm 0.1 \mathrm{~K}$. Droplet conditioning is conducted at droplet temperatures of 291$294 \mathrm{~K}$. The ACC is calibrated by determination of the ice melting point and deliquescence relative humidities of various inorganic salts (Knopf and Koop, 2006; Knopf, 2006; Knopf and Lopez, 2009; Knopf and Rigg, 2011). The resulting uncertainty in $a_{\mathrm{w}}$ is \pm 0.01 . At equilibrium, ambient RH equals solution $a_{\mathrm{w}}$ (Koop et al., 2000), which results in droplets with diameters ranging from 20 to $80 \mu \mathrm{m}$ of identical composition (Knopf and Lopez, 2009; Knopf and Rigg, 2011). After conditioning, the droplet sample is sealed against the environment by using a second hydrophobically coated glass slide serving as a cover and a tin foil spacer coated with high-vacuum grease. Hence, droplet composition is fixed for the remainder of the experiments according to the conditioning procedure. Subsequent ice nucleation experiments in which the aerosol sample is cooled will not significantly change droplet composition, since the amount of water vapor within the sealed aerosol sample that can condense onto the droplets is negligible compared to the amount of the condensed-phase water (Koop et al., 1998; Knopf et al., 2002; Knopf and Lopez, 2009). All sample preparation steps were done on a clean bench, thereby reducing the possibility of contamination from airborne particles (Knopf and Lopez, 2009; Knopf and Rigg, 2011).

Optical microscopy applying objectives with up to $100 \times$ magnification coupled to a CCD camera and digital imaging analysis software confirmed the presence of PP and LEO particles within the micrometer-sized water and aqueous $\left(\mathrm{NH}_{4}\right)_{2} \mathrm{SO}_{4}$ solution droplets. For estimation of PP and LEO surface areas within a single droplet, water droplets containing LEO and PP were generated. Promptly after droplet generation, the water evaporated leaving behind PP and LEO associated with a single droplet. Scanning electron microscopy 
Table 2. Surface area estimates applying analysis of scanning electron microscopy (SEM) images and Brunauer-Emmett-Teller (BET) gas adsorption technique.

\begin{tabular}{lll}
\hline Method & Leonardite & Pahokee peat \\
\hline SEM per droplet & $(6.6 \pm 0.89) \times 10^{-7} \mathrm{~cm}^{2}$ & $(1.2 \pm 0.24) \times 10^{-5} \mathrm{~cm}^{2}$ \\
BET & $(4.84 \pm 0.08) \mathrm{m}^{2} \mathrm{~g}^{-1}$ & $(9.0 \pm 0.3) \mathrm{m}^{2} \mathrm{~g}^{-1}$ \\
BET per droplet & $(7.6 \pm 0.1) \times 10^{-7} \mathrm{~cm}^{2}$ & $(1.4 \pm 0.05) \times 10^{-6} \mathrm{~cm}^{2}$ \\
\hline
\end{tabular}

(SEM) imaging analysis further corroborated the presence of organic particles within the generated droplets and allowed for estimation of PP and LEO surface areas. Surface area estimates derived from 10 droplets are given in Table 2. In addition, surface areas of PP and LEO were determined using the Brunauer-Emmett-Teller (BET) gas adsorption technique (Brunauer et al., 1938). Both PP and LEO preparation for the BET analysis involved crushing the organic material using a mortar and pestle. The resulting BET-determined surface areas are given in Table 2, indicating that PP exhibits almost double the surface area per weight compared to LEO, similar to the findings of a previous study (Hanzlík et al., 2004). For LEO, SEM- and BET-estimated surface areas are very similar. However, for PP, the SEM-based surface area estimates are about a factor of 8 larger than the ones derived from BET analysis. A possible reason for this difference is that PP and LEO remain anhydrous when examined by BET and thus their macromolecular size and orientation remains mostly unchanged. However, for SEM-derived surface areas, these particles are placed in water and parts of these macromolecules may dissolve or rearrange, thereby altering their size, orientation, or lead to breakup of particulate aggregates with subsequent effects on the visible condensed-phase surface area. For the remainder of this work, we apply the BETobtained surface areas for ice nucleation analysis.

\subsection{Ice nucleation apparatus}

The experimental setup is based on our previous studies (Knopf, 2006; Knopf and Lopez, 2009; Knopf and Rigg, 2011; Knopf and Forrester, 2011; Alpert et al., 2011a,b) and only described briefly here. The ice nucleation apparatus consists of a cryo-cooling stage coupled to an optical microscope equipped with digital imaging analysis, which allows controlled cooling and heating of the droplets. Ice nucleation was investigated applying a cooling rate of $10 \mathrm{~K} \mathrm{~min}^{-1}$ until all droplets froze. Subsequently, corresponding ice melting points were determined using a heating rate of $0.5 \mathrm{~K} \mathrm{~min}^{-1}$. The temperature is calibrated by measuring known melting points of ice and various organic species (Knopf, 2006; Knopf and Lopez, 2009; Knopf and Rigg, 2011). The temperature uncertainty is $\pm 0.1 \mathrm{~K}$. For aqueous $\left(\mathrm{NH}_{4}\right)_{2} \mathrm{SO}_{4}$ solutions it has been shown experimentally and by thermodynamic models (Bertram et al., 2000; Knopf and Lopez, 2009; Clegg et al., 1998) that $a_{\mathrm{w}}$ does not change signifi- cantly with temperature for the investigated $a_{\mathrm{w}}$ range. For this reason, droplet $a_{\mathrm{w}}$ and corresponding uncertainty as defined by the droplet conditioning procedure apply to the ice nucleation experiments observed at lower temperatures. Every $0.2 \mathrm{~K}$ during the freezing and melting cycles an image is recorded that contains experimental time and temperature. For each investigated $a_{\mathrm{w}}$, at least two independently prepared droplet samples were applied. Each droplet sample was used twice for observation of freezing and melting events. This results in a total of at least 1600 individually analyzed freezing and melting events. Once the experiment is completed, the freezing and melting temperatures of each droplet in a single experiment are determined.

\subsection{Chemicals}

$\mathrm{N}_{2}(99.999 \%)$ was purchased from Praxair. $\left(\mathrm{NH}_{4}\right)_{2} \mathrm{SO}_{4}$ $(99.95 \%)$ was purchased from Alfa Aesar. Humic acid reference Pahokee peat $(1 \mathrm{R} 103 \mathrm{H})$ and humic acid standard leonardite $(1 \mathrm{~S} 104 \mathrm{H})$ were purchased from the International Humic Substances Society (IHSS). Millipore water (resistivity $\geq 18.2 \mathrm{M} \Omega \mathrm{cm}$ ) was used for preparation of aqueous solutions.

\section{Results and discussion}

\subsection{Experimentally derived freezing temperatures}

Median freezing temperatures with 10th and 90th percentiles of water and aqueous $\left(\mathrm{NH}_{4}\right)_{2} \mathrm{SO}_{4}$ droplets containing LEO, $\tilde{T}_{\mathrm{f}}^{\mathrm{LEO}}$, and PP, $\tilde{T}_{\mathrm{f}}^{\mathrm{PP}}$, particles are shown in Fig. 1a and b, respectively, as a function of $T$ and $a_{\mathrm{w}}$ defined at droplet preparation conditions. Since direct measurements of $a_{\mathrm{w}}$ for supercooled aqueous $\left(\mathrm{NH}_{4}\right)_{2} \mathrm{SO}_{4}$ droplets do not exist, we assume that $a_{\mathrm{w}}$ does not change significantly with decreasing $T$ (Knopf and Lopez, 2009). Within the experimental uncertainty, mean melting temperatures of water and aqueous $\left(\mathrm{NH}_{4}\right)_{2} \mathrm{SO}_{4}$ droplets containing LEO and PP are in good agreement with the ice melting curve (Koop et al., 2000; Clegg et al., 1998). Agreement of measured ice melting temperatures with expected melting points (Koop and Zobrist, 2009; Clegg et al., 1998) indicates negligible effects on droplet $a_{\mathrm{w}}$ and composition due to the presence of LEO or PP. $\tilde{T}_{\mathrm{f}}^{\mathrm{LEO}}$ and $\tilde{T}_{\mathrm{f}}^{\mathrm{PP}}$ and corresponding melting points as a function of $\left(\mathrm{NH}_{4}\right)_{2} \mathrm{SO}_{4} \mathrm{wt} \%$ content are given in Fig. S1. Furthermore, we analyzed immersion freezing temperatures as a function of aqueous droplet volume. As shown in Figs. S2 and S3, no dependence of freezing temperatures on droplet volumes for LEO and PP is observed. This is similar to our previous findings by Alpert et al. (2011a). This finding may not be surprising when considering that water at interfaces fluctuates on timescales of subpicoseconds (McGuire and Shen, 2006), implying that the water clusters at the IN surface are not influenced by water further away within the droplet. Also, the homogeneous ice nucleation 
rate is negligible at these heterogeneous freezing temperatures and droplet volumes (Koop et al., 2000).

Figure 1 shows the predicted homogeneous freezing curves that are adjusted for the average droplet diameter of our samples representing $J_{\text {hom }}=2.18 \times 10^{6} \mathrm{~cm}^{-3} \mathrm{~s}^{-1}$ (Koop and Zobrist, 2009). $\tilde{T}_{\mathrm{f}}^{\mathrm{LEO}}$ and $\tilde{T}_{\mathrm{f}}^{\text {PP }}$ are about 5 to $15 \mathrm{~K}$ warmer than homogeneous freezing temperatures for high to low $a_{\mathrm{w}}$ indicating the ice nucleation efficiency of LEO and PP. At determined freezing temperatures and $a_{\mathrm{w}}<1$, these HULIS surrogates may be in a solid (glassy) state, as inferred by a previous study employing fulvic acid particles as IN (Young and Leboeuf, 2000; Koop and Zobrist, 2009; Wang et al., 2012a). Furthermore, the measured freezing points follow a similar $a_{\mathrm{w}}$ dependency as the homogeneous freezing curve. Hence, we represent $\tilde{T}_{\mathrm{f}}^{\text {LEO }}$ and $\tilde{T}_{\mathrm{f}}^{\text {PP }}$ by a shifted ice melting curve as suggested by previous studies (Zuberi et al., 2002; Archuleta et al., 2005; Cantrell and Robinson, 2006; Zobrist et al., 2008; Koop and Zobrist, 2009; Knopf et al., 2011; Knopf and Forrester, 2011; Alpert et al., 2011a,b). These heterogeneous ice nucleation curves are constructed by fitting $\tilde{T}_{\mathrm{f}}$ to

$a_{\mathrm{w}}^{\text {het }}\left(\tilde{T}_{\mathrm{f}}\right)=a_{\mathrm{w}}^{\text {ice }}(T)+\Delta a_{\mathrm{w}, \text { het }}$,

where $a_{\mathrm{w}}^{\text {ice }}(T)$ represents the thermodynamically given ice melting curve (Koop and Zobrist, 2009) and $\Delta a_{\mathrm{w}, \text { het }}$ is the only free parameter. The best fit yields for LEO-containing particles $\Delta a_{\mathrm{w}, \text { het }}^{\mathrm{LEO}}=0.2703$, as indicated by the solid line in Fig. 1a. PP nucleates ice at higher temperatures compared to LEO, resulting in a lower $\Delta a_{\mathrm{w}, \text { het }}^{\mathrm{pp}}=0.2466$, which is shown as the solid line in Fig. 1b. Within experimental uncertainties both data sets are well represented by the modified $a_{\mathrm{w}}$-based ice nucleation approach, which is thus sufficient to describe and predict immersion freezing temperatures of LEO and PP particles in water and aqueous $\left(\mathrm{NH}_{4}\right)_{2} \mathrm{SO}_{4}$ droplets. Koop and Zobrist (2009) found that $\Delta a_{\mathrm{w} \text {,het }}$ does not depend on solute type. Similarly, we suggest that only $a_{\mathrm{w}}$, and thus RH, can be applied as a valid description of immersion freezing induced by LEO and PP independent of the nature of the solute.

\subsection{Kinetic analysis of freezing data}

The freezing data are analyzed applying five different descriptions of the parameters governing ice nucleation. First it is assumed that each ice nucleation event occurring at a specific temperature can be described by a corresponding contact angle, $\alpha$, between the ice nucleus and the ice embryo, which we term $\alpha(T)$-model (Zobrist et al., 2007; Knopf and Forrester, 2011; Wang and Knopf, 2011; Alpert et al., 2011a,b). This implies that $\alpha$ varies with temperature and does not represent a fixed parameter for similar IN. Second, a single contact angle is attributed among similar IN, termed single- $\alpha$ model (Marcolli et al., 2007; Lüönd et al., 2010). Third, a probability density function (PDF) to distribute $\alpha$ among similar IN is applied, termed $\alpha$-PDF model (Marcolli

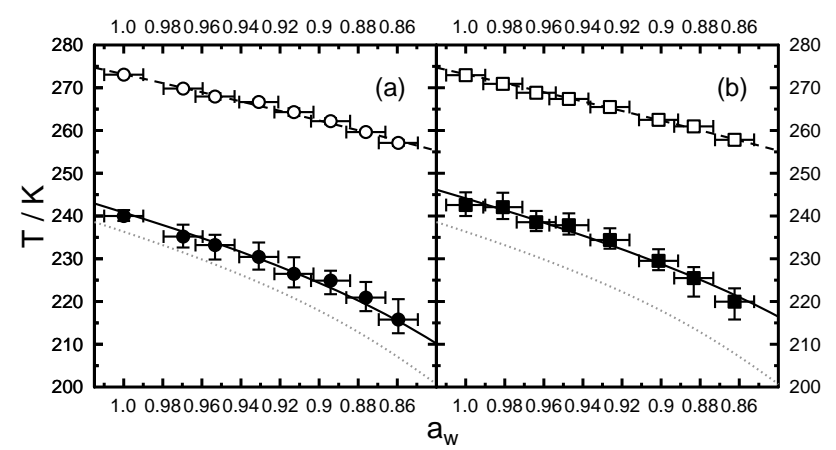

Fig. 1. Experimentally derived median freezing temperatures with 10 th and 90th percentiles and mean melting temperatures with $\pm 1 \sigma$ of leonardite in water and aqueous $\left(\mathrm{NH}_{4}\right)_{2} \mathrm{SO}_{4}$ droplets (a), and $\mathrm{Pa}$ hokee peat in water and aqueous $\left(\mathrm{NH}_{4}\right)_{2} \mathrm{SO}_{4}$ droplets (b) are shown as a function of $a_{\mathrm{w}}$ determined at particle preparation conditions. Ice melting and homogeneous freezing curves are plotted as dashed and dotted lines, respectively (Koop and Zobrist, 2009). The homogeneous freezing curve represents $J_{\mathrm{hom}}=2.18 \times 10^{6} \mathrm{~cm}^{-3} \mathrm{~s}^{-1}$. The solid lines are best fits based on the data in which the ice melting curves are shifted by $\Delta a_{\mathrm{W}}=0.2703$ for leonardite in (a) and by $\Delta a_{\mathrm{W}}=0.2466$ for Pahokee peat in (b). The derived freezing curves represent $J_{\text {het }}^{\exp }=(9.6 \pm 2.5) \times 10^{4}$ and $(5.4 \pm 1.4) \times 10^{4} \mathrm{~cm}^{-2} \mathrm{~s}^{-1}$ for leonardite (a) and Pahokee peat (b), respectively. It is assumed that $a_{\mathrm{w}}$ does not change with temperature.

et al., 2007; Lüönd et al., 2010). Fourth, randomly sampled ice nucleating sites with the same surface area but different $\alpha$ are distributed on each of the IN surfaces, termed active sites model (Marcolli et al., 2007; Lüönd et al., 2010). Lastly, it is assumed that ice nucleation does not significantly depend on time, and thus ice nucleation can be described as a function of temperature and IN surface areas only, termed the deterministic model (Vali, 1971; Alpert et al., 2011a,b). These ice nucleation descriptions have been derived and discussed in detail in previous literature (Zobrist et al., 2007; Alpert et al., 2011a,b; Marcolli et al., 2007; Lüönd et al., 2010). The correctness of the underlying mathematical analysis applied here using single- $\alpha, \alpha$-PDF, active sites, and deterministic model described below has been validated by reproduction of the results by Lüönd et al. (2010). It should be noted that a constant cooling rate is applied in our experiments and that the frozen and unfrozen number of droplets and corresponding nucleation time and temperature are known for each investigated temperature interval throughout the entire experiment.

\subsubsection{Derivation of heterogeneous ice nucleation rate coefficients}

Each individually observed freezing event occurring at temperature $T$ is analyzed to yield a heterogeneous ice nucleation rate coefficient, $J_{\text {het }}^{\exp }(T)$, and $\alpha(T) . J_{\text {het }}$ is calculated for all experimentally acquired data according to the equation 
(Zobrist et al., 2007; Knopf and Forrester, 2011; Alpert et al., 2011a,b):

$J_{\text {het }}^{\exp }\left(T^{i}\right)=\frac{n_{\text {nuc }}^{i}}{t_{\mathrm{tot}}^{i} \cdot A^{i}}$,

where $n_{\text {nuc }}^{i}$ is the number of freezing events, $t_{\text {tot }}^{i} \cdot A^{i}$ is the product of the total observation time and surface area, and $T^{i}$ is the mean ice nucleation temperature in the $i$-th temperature interval. The product $t_{\mathrm{tot}}^{i} \cdot A^{i}$ is the sum of the contribution from the droplets that remain liquid and those that freeze according to

$t_{\mathrm{tot}}^{i} \cdot A^{i}=\frac{\Delta T}{\mathrm{cr}} A_{\mathrm{rm}}^{i}+\sum_{j=1}^{n_{\mathrm{nuc}}^{i}} \frac{1}{\mathrm{cr}}\left(T_{\mathrm{st}}^{i}-T_{\mathrm{nuc}, j}^{i}\right) A_{j}^{i}$,

where $\mathrm{cr}$ is the experimental cooling rate, $A_{\mathrm{rm}}^{i}$ is the total surface area remaining until the end of the temperature interval, $T_{\mathrm{st}}^{i}$ is the start of the temperature interval, and $T_{\mathrm{nuc}, j}^{i}$ and $A_{j}^{i}$ are the freezing temperature and corresponding ice nucleus surface area, respectively, of the $j$-th droplet nucleating ice within the $i$-th interval. Derivations of $J_{\text {het }}^{\exp }\left(T^{i}\right)$ employ $\Delta T=0.2 \mathrm{~K}$. It should be noted that no further assumptions or information such as the diffusion coefficient of water in supercooled aqueous solutions, interfacial surface tensions between ice nucleus and surrounding medium, distribution of contact angles, or active sites are employed to derive $J_{\text {het }}^{\exp }(T)$, but only the number of freezing events are counted and related to the available IN surface areas and time the droplets stay liquid. Hence, this analysis of the underlying nucleation kinetics is solely based on experimental data omitting any prescribed or fitted parameters.

Figures $2 \mathrm{a}$ and $3 \mathrm{a}$ show experimentally derived $J_{\text {het }}^{\exp }$ as a function of $T$ and $a_{\mathrm{w}}$ for LEO and PP containing droplets, respectively. For each droplet $a_{\mathrm{w}}, J_{\text {het }}^{\text {exp }}$ increases exponentially with decreasing $T$. For a given $a_{\mathrm{w}}$, a temperature decrease of about $10 \mathrm{~K}$ results in an increase of $J_{\text {het }}^{\text {exp }}$ by over 2 orders of magnitude. It should be noted that homogeneous ice nucleation is unlikely to have affected derived $J_{\text {het }}$ since homogeneous ice nucleation rates $1-2 \mathrm{~K}$ above the expected homogeneous freezing curve shown in Fig. 1 are too slow to induce freezing under applied experimental timescales (Koop et al., 2000). A summary of $J_{\text {het }}^{\text {exp }}$ values for each $a_{\mathrm{w}}$ derived at $\tilde{T}_{\mathrm{f}}$ is given in Tables 3 and 4 for LEO and PP, respectively, and indicate that $J_{\text {het }}^{\exp }\left(\tilde{T}_{\mathrm{f}}\right)$ are almost constant, changing by only about a factor of 2 along the corresponding freezing curve (Fig. 1) constructed by shifting the ice melting curve by its respective $\Delta a_{\mathrm{w}, \text { het }}$. Thus, both of the experimentally determined freezing curves can be assigned a constant $J_{\text {het }}^{\text {exp }}$ value similar to the findings of the $a_{\mathrm{w}}$-based homogeneous ice nucleation description (Koop et al., 2000; Koop and Zobrist, 2009). Determined at $\tilde{T}_{\mathrm{f}}, J_{\text {het }}^{\exp }$ are $(9.6 \pm 2.5) \times 10^{4}$ and $(5.4 \pm 1.4) \times 10^{4} \mathrm{~cm}^{-2} \mathrm{~s}^{-1}$ for the freezing curves of LEO and PP containing droplets, respectively.

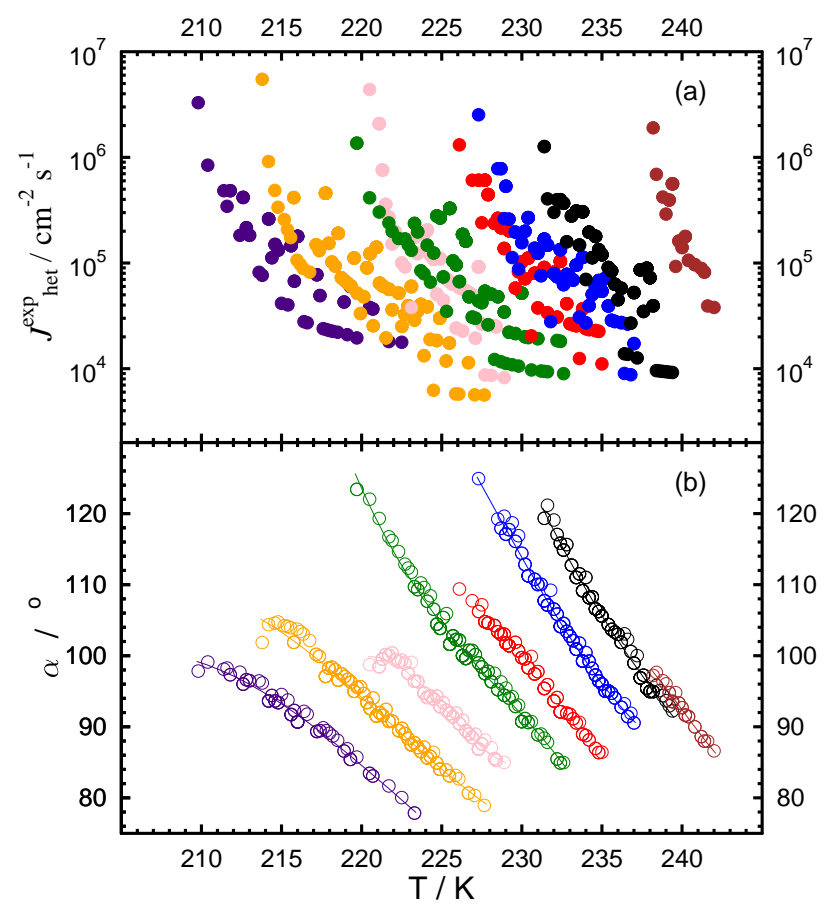

Fig. 2. (a) shows experimentally derived heterogeneous ice nucleation rate coefficients, $J_{\text {het }}^{\exp }$, and (b) corresponding contact angles, $\alpha$, of leonardite / water and aqueous leonardite / $\left(\mathrm{NH}_{4}\right)_{2} \mathrm{SO}_{4}$ droplets shown as a function of temperature and $a_{\mathrm{w}}$. Brown, black, blue, red, green, pink, orange, and purple circles represent the initial $a_{\mathrm{W}}$ of $1.00,0.971,0.953,0.931,0.913,0.892,0.872$, and 0.851 , respectively. Lines indicate a third-order polynomial fit.

\subsection{2 $\alpha(T)$-model}

Experimentally derived values of $J_{\text {het }}^{\exp }$ are used to calculate $\alpha$, which represents the contact angle between the ice nucleus and the ice embryo in an aqueous medium (Zobrist et al., 2007). $\alpha$ is derived from the compatibility factor, $f_{\text {het }}$, which describes the reduction in Gibbs free energy of formation compared to homogeneous ice nucleation, $\Delta G_{\text {act }}(T)$, due to the presence of an ice nucleus according to (Pruppacher and Klett, 1997)

$f_{\text {het }}=\frac{1}{4}(2+\cos \alpha)(1-\cos \alpha)^{2}$.

An $f_{\text {het }}$ value of 1 , corresponding to $\alpha=180^{\circ}$, indicates no reduction in Gibbs free energy equivalent to homogeneous ice nucleation; that is, the ice nucleus does not enhance the ice nucleating abilities of the bulk phase, and a value of $0^{\circ}$ implies perfect compatibility between the ice nucleus and the ice embryo, yielding vanishing Gibbs free energy (Pruppacher and Klett, 1997; Zobrist et al., 2007). The derivation of $f_{\text {het }}$ follows previous studies (Zobrist et al., 2007; Knopf and Forrester, 2011; Alpert et al., 2011a,b) and is only briefly introduced here. $f_{\text {het }}$ is calculated from experimentally derived $J_{\text {het }}$ by 
Table 3. Immersion freezing from water and aqueous ammonium sulfate particles containing leonardite (LEO). The following are given as a function of solution water activity, $a_{\mathrm{w}}$ : mean melting temperature $\left(T_{\text {melt }}^{\mathrm{LEO}} \pm 1 \sigma\right)$, median freezing temperature $\left(\tilde{T}_{\mathrm{f}}^{\mathrm{LEO}}\right.$, with 10 th and 90 th percentiles), supersaturation with respect to ice $\left(S_{\text {ice }}\right.$, at $\left.\tilde{T}_{\mathrm{f}}^{\mathrm{LEO}}\right)$; heterogeneous ice nucleation rate coefficient $\left(J_{\text {het }}^{\text {exp }}\right.$, at $\left.\tilde{T}_{\mathrm{f}}^{\mathrm{LEO}}\right)$, contact angle $\alpha$ at $\tilde{T}_{\mathrm{f}}^{\mathrm{LEO}}$, and fit parameters for $\alpha(T)$, single- $\alpha, \alpha$-PDF, active sites, and deterministic model.

\begin{tabular}{|c|c|c|c|c|c|c|c|c|c|}
\hline \multirow[t]{2}{*}{ Model } & \multirow[t]{2}{*}{ Parameter } & \multicolumn{8}{|c|}{$a_{\mathrm{W}}$} \\
\hline & & 1.0 & 0.971 & 0.953 & 0.931 & 0.913 & 0.892 & 0.872 & 0.851 \\
\hline & $T_{\text {melt }}^{\mathrm{LEO}}[\mathrm{K}]$ & $273.06 \pm 0.2$ & $269.81 \pm 0.4$ & $267.95 \pm 0.8$ & $266.65 \pm 0.6$ & $264.30 \pm 0.9$ & $262.18 \pm 0.7$ & $259.63 \pm 0.5$ & $257.10 \pm 0.7$ \\
\hline & $\tilde{T}_{\mathrm{f}}^{\mathrm{LEO}}[\mathrm{K}]$ & $240.00_{-1.16}^{+1.38}$ & $235.19_{-2.56}^{+2.78}$ & $233.20_{-3.38}^{+2.40}$ & $230.43_{-2.59}^{+3.37}$ & $226.47^{+3.88}$ & $224.88^{+2.32}$ & $220.92^{+3.65}$ & $215.77^{+4.78}$ \\
\hline & $S_{\text {ice }}$ & $\begin{array}{r}-1.10 \\
1.38\end{array}$ & $\begin{array}{r}1.40 \\
\end{array}$ & $\begin{array}{r}-5.30 \\
1.40\end{array}$ & 1.40 & 1.43 & 1.41 & 1.42 & 1.44 \\
\hline \multirow{6}{*}{$\alpha(T)$} & $J_{\text {het }}^{\exp }\left[10^{4} \mathrm{~cm}^{-2} \mathrm{~s}^{-1}\right]$ & 14.31 & 10.71 & 6.72 & 7.07 & 11.55 & 7.84 & 7.90 & 10.80 \\
\hline & $\alpha\left[^{\circ}\right]$ & 92.69 & 104.97 & 102.11 & 98.94 & 100.03 & 93.38 & 91.54 & 91.71 \\
\hline & $a \times 10^{-3}\left[{ }^{\circ} \mathrm{K}^{-3}\right]$ & 31.638 & -5.4285 & 6.4544 & 10.329 & -11.381 & 36.629 & 4.0442 & 22.945 \\
\hline & $b\left[{ }^{\circ} \mathrm{K}^{-2}\right]$ & -22.784 & 3.9432 & -4.4029 & -7.1818 & 7.8084 & -24.759 & -2.6883 & -1.5378 \\
\hline & $c \times 10^{3}\left[{ }^{\circ} \mathrm{K}^{-1}\right]$ & 5.4662 & -0.95753 & 0.99705 & 1.6617 & -1.7882 & 5.5762 & 0.59359 & 0.34158 \\
\hline & $d \times 10^{4}\left[{ }^{\circ}\right]$ & -43.681 & 7.7814 & -7.4826 & -12.785 & 13.678 & -41.834 & -4.3447 & 0.034158 \\
\hline \multirow[t]{2}{*}{ Single- $\alpha$} & $\alpha_{0}\left[{ }^{\circ}\right]$ & 91.50 & 104.16 & 99.58 & 128.22 & 99.24 & 92.47 & 90.70 & 115.35 \\
\hline & $\alpha\left[^{\circ}\right]$ & 91.15 & 102.20 & 100.04 & 96.21 & 97.99 & 91.55 & 90.19 & 90.40 \\
\hline \multirow[t]{2}{*}{$\alpha$-PDF } & $\mu$ & 0.4643 & 0.5223 & 0.5787 & 0.5183 & 0.5366 & 0.4686 & 0.4537 & 0.4560 \\
\hline & $\sigma$ & 0.0400 & 0.0857 & 0.085 & 0.0797 & 0.0754 & 0.0606 & 0.0719 & 0.0655 \\
\hline \multirow{3}{*}{ Active Sites } & $b \times 10^{7}\left[\mathrm{~cm}^{-2}\right]$ & 12.0 & 4.059 & 5.999 & 5.055 & 13.3 & 11.1 & 9.14 & 9.32 \\
\hline & $\beta_{1}$ & 0.125 & 0.184 & 0.188 & 0.183 & 0.498 & 0.187 & 0.193 & 0.113 \\
\hline & $\beta_{2}$ & 1.239 & 1.143 & 1.133 & 1.088 & 1.021 & 1.066 & 1.022 & 1.043 \\
\hline \multirow[t]{2}{*}{ Deterministic } & $a_{1}\left[10^{4} \mathrm{~cm}^{-2} \mathrm{~K}^{-2}\right]$ & 24.5 & 5.37 & 5.26 & 4.64 & 4.32 & 5.83 & 3.41 & 3.03 \\
\hline & $a_{2}[\mathrm{~K}]$ & 242.05 & 239.76 & 237.54 & 235.26 & 231.48 & 229.00 & 226.50 & 221.73 \\
\hline
\end{tabular}

Table 4. Immersion freezing from water and aqueous ammonium sulfate particles containing Pahokee peat (PP). The following are given as a function of solution water activity, $a_{\mathrm{W}}$ : mean melting temperature $\left(T_{\mathrm{melt}}^{\mathrm{PP}}, \pm 1 \sigma\right)$, median freezing temperature $\left(\tilde{T}_{\mathrm{f}}^{\mathrm{PP}}\right.$, with 10 th and 90 th percentiles), supersaturation with respect to ice $\left(S_{\text {ice }}\right.$, at $\left.\tilde{T}_{\mathrm{f}}^{\mathrm{PP}}\right)$; heterogeneous ice nucleation rate coefficient $\left(J_{\text {het }}^{\exp }\right.$, at $\left.\tilde{T}_{\mathrm{f}}^{\text {PP }}\right)$, contact angle $\alpha$ at $\tilde{T}_{\mathrm{f}}^{\mathrm{PP}}$, and fit parameters for $\alpha(T)$, single- $\alpha, \alpha$-PDF, active sites, and deterministic model.

\begin{tabular}{|c|c|c|c|c|c|c|c|c|c|}
\hline \multirow[t]{2}{*}{ Model } & \multirow[t]{2}{*}{ Parameter } & \multicolumn{8}{|c|}{$a_{\mathrm{W}}$} \\
\hline & & 1.0 & 0.981 & 0.964 & 0.947 & 0.926 & 0.901 & 0.883 & 0.862 \\
\hline & $\begin{array}{l}T_{\text {melt }}^{\mathrm{PP}}[\mathrm{K}] \\
\tilde{T}_{\mathrm{f}}^{\mathrm{PP}}[\mathrm{K}] \\
S_{\text {ice }}\end{array}$ & $\begin{array}{r}272.94 \pm 0.1 \\
242.57^{+3.0}-2.6 \\
1.35\end{array}$ & $\begin{array}{r}270.91 \pm 0.3 \\
242.07^{+3.37}-2.78 \\
1.33\end{array}$ & $\begin{array}{r}268.83 \pm 0.3 \\
238.55_{-2.08}^{+2.63} \\
1.34\end{array}$ & $\begin{array}{r}267.38 \pm 0.3 \\
237.85_{-2.19}^{+2.77} \\
1.33\end{array}$ & $\begin{array}{r}265.49 \pm 0.4 \\
234.39^{+2.74}-2.04 \\
1.35\end{array}$ & $\begin{array}{r}262.49 \pm 0.5 \\
229.51_{-2.72}^{+2.18} \\
1.37\end{array}$ & $\begin{array}{r}260.96 \pm 0.6 \\
225.48_{-4.33}^{+2.57} \\
1.40\end{array}$ & $\begin{array}{r}257.82 \pm 0.5 \\
219.96_{-4.17}^{+3.12} \\
1.42\end{array}$ \\
\hline \multirow{6}{*}{$\alpha(T)$} & $J_{\mathrm{ht}}^{\exp }\left[10^{4} \mathrm{~cm}^{-2} \mathrm{~s}^{-1}\right]$ & 3.60 & 4.73 & 4.68 & 5.79 & 6.59 & 5.78 & 8.11 & 3.89 \\
\hline & $\alpha\left[^{\circ}\right]$ & 84.51 & 86.77 & 89.45 & 83.21 & 84.44 & 85.54 & 86.98 & 90.35 \\
\hline & $a \times 10^{-3}\left[{ }^{\circ} \mathrm{K}^{-3}\right]$ & 2.3951 & 1.1471 & 17.810 & 12.377 & 13.111 & -93.389 & 10.971 & 32.564 \\
\hline & $b\left[{ }^{\circ} \mathrm{K}^{-2}\right]$ & -1.6356 & -0.78175 & -1.2775 & -8.8617 & -0.92924 & 6.3971 & -7.3661 & -2.1540 \\
\hline & $c \times 10^{3}\left[{ }^{\circ} \mathrm{K}^{-1}\right]$ & 0.36770 & 0.17371 & 3.0516 & 2.1123 & 0.21714 & -1.4626 & 1.6463 & 0.47296 \\
\hline & $d \times 10^{5}\left[{ }^{\circ}\right]$ & -0.27053 & -12.426 & -2.4266 & -1.6755 & -0.16642 & 1.1171 & -1.2239 & -0.34383 \\
\hline \multirow[t]{2}{*}{ Single- $\alpha$} & $\alpha_{0}\left[{ }^{\circ}\right]$ & 83.92 & 85.51 & 88.33 & 82.29 & 83.32 & 84.65 & 85.97 & 88.25 \\
\hline & $\alpha\left[^{\circ}\right]$ & 83.75 & 85.33 & 87.51 & 81.89 & 82.53 & 84.86 & 85.70 & 88.77 \\
\hline \multirow[t]{2}{*}{$\alpha-\mathrm{PDF}$} & $\mu$ & 0.3796 & 0.3983 & 0.4235 & 0.3571 & 0.3650 & 0.3927 & 0.4026 & 0.4378 \\
\hline & $\sigma$ & 0.0678 & 0.0877 & 0.0678 & 0.0675 & 0.0626 & 0.0490 & 0.0523 & 0.0707 \\
\hline \multirow{3}{*}{ Active Sites } & $b \times 10^{8}\left[\mathrm{~cm}^{-2}\right]$ & 2.9827 & 2.9022 & 2.3871 & 3.0485 & 3.0864 & 3.0058 & 3.0146 & 3.0864 \\
\hline & $\beta_{1}$ & 1.3601 & 1.0697 & 0.9500 & 0.8580 & 0.6810 & 0.7248 & 0.7443 & 0.8008 \\
\hline & $\beta_{2}$ & 0.9075 & 0.9507 & 0.9899 & 0.9577 & 1.0062 & 1.0143 & 1.0155 & 1.0296 \\
\hline \multirow[t]{2}{*}{ Deterministic } & $a_{1}\left[10^{4} \mathrm{~cm}^{-2} \mathrm{~K}^{-2}\right]$ & 2.59 & 3.43 & 4.25 & 4.00 & 4.75 & 6.07 & 4.38 & 1.78 \\
\hline & $a_{2}[\mathrm{~K}]$ & 245.80 & 246.16 & 242.33 & 241.72 & 238.02 & 232.52 & 229.22 & 225.26 \\
\hline
\end{tabular}


$J_{\text {het }}(T, \alpha)=\frac{k T}{h} \exp \left[-\frac{\Delta F_{\text {diff }}(T)}{k T}\right] n \exp \left[-\frac{\Delta G_{\text {act }}(T) f_{\text {het }}(\alpha)}{k T}\right]$,

where $k$ and $h$ are the Boltzmann and Planck constants, respectively, $n$ is the number density of water molecules at the ice-nucleus-water interface, and $\Delta F_{\text {diff }}(T)$ is the diffusion activation energy of a water molecule to cross the water-iceembryo interface (Pruppacher and Klett, 1997). $\Delta F_{\text {diff }}(T)$ and $\Delta G_{\text {act }}(T)$ are dictated by the properties of the aqueous $\left(\mathrm{NH}_{4}\right)_{2} \mathrm{SO}_{4}$ solution such as water diffusivity, $D_{\mathrm{H}_{2} \mathrm{O}}^{\left(\mathrm{NH}_{4}\right)_{2} \mathrm{SO}_{4}}$, and the solid-liquid interfacial tension of the ice embryo, $\sigma_{\text {sl }}^{\left(\mathrm{NH}_{4}\right)_{2} \mathrm{SO}_{4}}$, respectively (Zobrist et al., 2007; Knopf and Forrester, 2011; Alpert et al., 2011a,b). In the case of LEO and PP containing water droplets, $D_{\mathrm{H}_{2} \mathrm{O}}^{\mathrm{H}_{2} \mathrm{O}}$ (Smith and Kay, 1999) and $\sigma_{\mathrm{sl}}^{\mathrm{H}_{2} \mathrm{O}}$ are applied following Zobrist et al. (2007).

Tanaka (1975) experimentally determined $D_{\mathrm{H}_{2} \mathrm{O}}^{\left(\mathrm{NH}_{4}\right)_{2} \mathrm{SO}_{4}}$ for aqueous $\left(\mathrm{NH}_{4}\right)_{2} \mathrm{SO}_{4}$ solutions $0.75-6.46 \mathrm{wt} \%$ in concentration at $298 \mathrm{~K}$ and at temperatures $278-308 \mathrm{~K}$ for an aqueous $\left(\mathrm{NH}_{4}\right)_{2} \mathrm{SO}_{4}$ solution $0.75 \mathrm{wt} \%$ in concentration. The change in diffusion coefficients with $T$ of pure water, $D_{\mathrm{H}_{2} \mathrm{O}}^{\mathrm{H}_{2} \mathrm{O}}$ (Smith and Kay, 1999) and $D_{\mathrm{H}_{2} \mathrm{O}}^{\left(\mathrm{NH}_{4}\right)_{2} \mathrm{SO}_{4}}$ determined by Tanaka (1975) are very similar. We assume a similar temperature dependence is also true for aqueous $\left(\mathrm{NH}_{4}\right)_{2} \mathrm{SO}_{4}$ solutions of higher concentrations typical of our investigated aqueous $\left(\mathrm{NH}_{4}\right)_{2} \mathrm{SO}_{4}$ droplets. Hence, we use $D_{\mathrm{H}_{2} \mathrm{O}}^{\mathrm{H}_{2} \mathrm{O}}(T)$ to describe $D_{\mathrm{H}_{2} \mathrm{O}}^{\left(\mathrm{NH}_{4}\right)_{2} \mathrm{SO}_{4}}(T)$. As previously discussed, potential uncertainties arising using $D_{\mathrm{H}_{2} \mathrm{O}}^{\mathrm{H}_{2} \mathrm{O}}$ are expected to be negligible as $\Delta F_{\text {diff }}$ is proportional to $\frac{d \ln \left(D_{\mathrm{H}_{2} \mathrm{O}}^{\left(\mathrm{NH}_{4}\right)_{2} \mathrm{SO}_{4}}(T)\right)}{d T}$ (Knopf and Forrester, 2011; Alpert et al., 2011b). Thus, uncertainties in $D_{\mathrm{H}_{2} \mathrm{O}}^{\left(\mathrm{NH}_{4}\right)_{2} \mathrm{SO}_{4}}$ are expected to have a small effect on $J_{\text {het }}$ (and thus on $\alpha$ ) since the derivative with respect to temperature is not expected to change significantly.

The derivation of $\Delta G_{\text {act }}(T)$ for aqueous $\left(\mathrm{NH}_{4}\right)_{2} \mathrm{SO}_{4}$ is dependent upon $\sigma_{\mathrm{sl}}^{\left(\mathrm{NH}_{4}\right)_{2} \mathrm{SO}_{4}}$, which has yet to be examined for the supercooled temperature region. For this reason, $\sigma_{\mathrm{sl}}^{\left(\mathrm{NH}_{4}\right)_{2} \mathrm{SO}_{4}}(T)$ is derived for each $a_{\mathrm{W}}$ from the $a_{\mathrm{W}^{-}}$ based homogeneous ice nucleation description as previously discussed in detail (Alpert et al., 2011b). In short, $\sigma_{\mathrm{sl}}^{\left(\mathrm{NH}_{4}\right)_{2} \mathrm{SO}_{4}}(T)$ is calculated from Eq. (5) setting $f_{\text {het }}=1$ and and replacing $n$ for $n_{\mathrm{v}}$, which describes the volume number density of water molecules in liquid water and corresponding $J_{\text {hom }}\left(\Delta a_{\mathrm{w}, \text { het }}\right)$ from the $a_{\mathrm{w}}$-based homogeneous ice nucleation description (Koop et al., 2000; Koop and Zobrist, 2009).

Figures $2 \mathrm{~b}$ and $3 \mathrm{~b}$ show $\alpha$ as a function of $T$ and $a_{\mathrm{w}}$ for LEO and PP containing water and aqueous $\left(\mathrm{NH}_{4}\right)_{2} \mathrm{SO}_{4}$ droplets, respectively. As temperature decreases by about $10 \mathrm{~K}, \alpha$ increases by approximately $20^{\circ}$. Furthermore, for the same freezing temperatures, $\alpha$ varies for different $a_{\mathrm{w}}$ indicating the effect of the solute on the water hydrogen bonding network (Knopf and Rigg, 2011; Alpert et al., 2011b) and

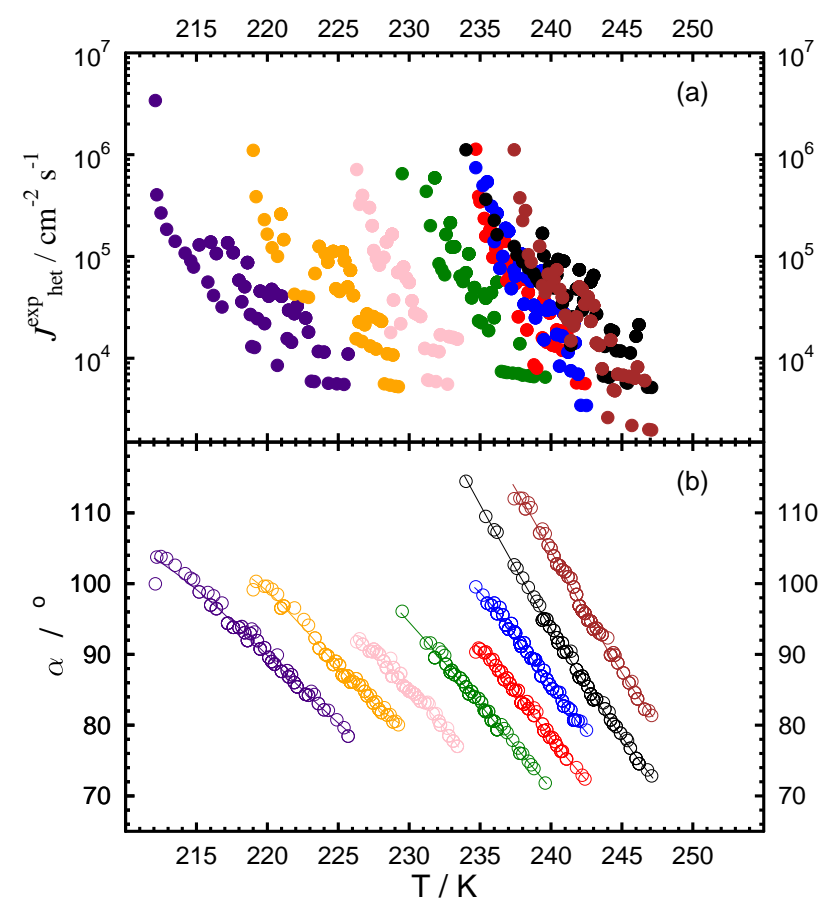

Fig. 3. (a) shows experimentally derived heterogeneous ice nucleation rate coefficients, $J_{\text {het }}^{\text {exp }}$, and (b) corresponding contact angles, $\alpha$, of Pahokee peat/water and aqueous Pahokee peat $/\left(\mathrm{NH}_{4}\right)_{2} \mathrm{SO}_{4}$ droplets shown as a function of temperature and $a_{\mathrm{w}}$. Brown, black, blue, red, green, pink, orange, and purple squares represent the initial $a_{\mathrm{w}}$ of $1.00,0.981,0.964,0.947,0.926,0.901,0.883$, and 0.862 , respectively. Lines indicate a third-order polynomial fit.

thus on the ice nucleation process. Evaluated at $\tilde{T}_{\mathrm{f}}, \alpha$ is given in Tables 3 and 4 for LEO and PP, respectively. We also represent $\alpha(T)$ as a third-order polynomial fit, valid over the experimentally applied temperature range shown in Figs. $2 b$ and $3 \mathrm{~b}$. Corresponding fit parameters are listed in Tables 3 and 4.

These results are very similar to previous findings (Zobrist et al., 2007; Knopf and Forrester, 2011; Alpert et al., $2011 \mathrm{a}, \mathrm{b})$ corroborating the use of $\alpha(T)$ for describing immersion freezing. The contact angle is defined by Young's equation, which relates $\alpha$ to the three interfacial surface energies between the ice nucleus and ice, ice nucleus and aqueous solution (water), and ice and aqueous solution (Pruppacher and Klett, 1997; Alpert et al., 2011b). These interfacial surface energies are temperature dependent and will be affected by the presence of solutes. A recent study by Welti et al. (2012) also found that contact angle increases as temperature decreases. These authors derived, using physical parameterizations of the interfacial energies taken from Helmy et al. (2004) and Pruppacher and Klett (1997), a reasonable temperature-dependent interfacial energy between the IN surface and the ice embryo and thus corroborate the observed temperature dependency of the contact angle being a physical phenomenon. Zobrist et al. (2007) have shown that 
keeping the contact angle constant for all temperatures and varying the pre-exponential factor in Eq. (5) does not improve the representation of $J_{\text {het }}$ with temperature compared to the implementation of a contact angle that varies with temperature. Lastly, we have determined that when keeping the contact angle constant, $\sigma_{\mathrm{sl}}$ increases with decreasing $T$ in contrast to expected behavior (Pruppacher and Klett, 1997; Zobrist et al., 2007; Alpert et al., 2011b; Welti et al., 2012), further supporting a temperature-dependent contact angle exhibiting increasing contact angles with decreasing temperatures.

$J_{\text {het }}$ can be derived for a specific freezing temperature using laboratory-determined $\alpha(T)$, and Eq. (5) yielding the heterogeneous ice nucleation rate coefficient as a continuous function of $T, J_{\text {het }}^{\alpha}(T) . J_{\text {het }}^{\alpha}(T)$ can then be applied to predict ice nucleation rates or frozen fractions for IN surface areas and nucleation (cloud activation) times that were not probed in the laboratory. This is corroborated by the comparable results in $J_{\text {het }}^{\text {exp }}(T), J_{\text {het }}^{\alpha}(T)$, and $\alpha(T)$ between Zobrist et al. (2007), who used smaller IN surface areas, faster cooling rates, and observed lower freezing temperatures compared to the study by Knopf and Forrester (2011), who used larger surface areas, slower cooling rates, and observed higher freezing temperatures. These results allude to homogeneous ice nucleation, where the freezing rate scales with the volume and nucleation time (Pruppacher and Klett, 1997; Koop, 2004).

For each temperature interval, $i$, the frozen fraction can be derived. The experimentally derived cumulative frozen fraction for the entire freezing temperature range is given by

$f\left(T^{i}\right)=\frac{\sum_{i} N_{\mathrm{f}}^{i}}{N_{\mathrm{tot}}}$,

where $N_{\mathrm{f}}^{i}$ is the number of frozen droplets in the $i$-th temperature interval at $T^{i}$ with width $\Delta T$, and $N_{\text {tot }}$ is the total number of droplets; both parameters are readily available from the experimental data. The experimentally derived cumulative frozen fractions are shown in Figs. 4 and 5. At the median, i.e., $f=0.5,50 \%$ of all investigated droplets are frozen.

We can now reproduce the cumulative $f(T)$ using $J_{\text {het }}^{\text {exp }}$ derived from Eq. (2), i.e., directly from experimental data, or by using $\alpha(T)$, i.e., $J_{\text {het }}^{\alpha}$. We can express the change in the number of unfrozen droplets per temperature interval $i$ as

$\frac{N_{\mathrm{uf}}^{i}}{\mathrm{~d} t}=-J_{\mathrm{het}}(T) \bar{A} N_{\mathrm{uf}}^{i}$,

where $N_{\text {uf }}^{i}$ represents the number of unfrozen droplets remaining after cooling beyond the temperature interval $i$ and $\bar{A}$ is the mean ice nucleus surface area. With $\mathrm{d} t=\frac{\mathrm{d} T}{\mathrm{cr}}$ and integration from $N_{\text {tot }}$ to $N_{\text {uf }}^{i}$ yields

$\frac{N_{\mathrm{uf}}^{i}}{N_{\mathrm{tot}}}=\exp \left[-\frac{\bar{A}}{\mathrm{cr}} \int_{T_{\mathrm{melt}}}^{T^{i}} J_{\mathrm{het}}(T) \mathrm{d} T\right]$.
The number of frozen droplets of temperature interval $i$ is given as $N_{\mathrm{f}}^{i}=N_{\mathrm{tot}}-N_{\mathrm{uf}}^{i}$. Applying this to the previous equation results in

$\frac{N_{\mathrm{f}}^{i}}{N_{\text {tot }}}=f(T)=1-\exp \left[-\frac{\bar{A}}{c r} \int_{T_{\text {melt }}}^{T^{i}} J_{\text {het }}(T) \mathrm{d} T\right]$.

It is with no surprise that application of experimentally derived $J_{\text {het }}^{\exp }(T)$ reproduces experimentally derived $f$ exactly as shown by the crosses in Figs. 4 and 5 since its derivation is based on the very same data set. (Very minor differences are due to the application of $\bar{A}$ and mean temperature of the $i$-th temperature interval.)

As mentioned above $J_{\text {het }}^{\text {exp }}\left(\tilde{T}_{\mathrm{f}}\right)$ are almost constant along the freezing curve and thus with $\Delta a_{\mathrm{w}, \text { het }}$. However, this fact is not only true at $\tilde{T}_{\mathrm{f}}$ where $f=0.5$, but for every frozen fraction value. Upon closer inspection of Figs. 2a and 3 a note that $J_{\text {het }}^{\exp }$ span a similar range of values for the different investigated $a_{\mathrm{w}}$. Frozen fraction values at each $a_{\mathrm{w}}$ superimposed on $J_{\text {het }}^{\text {exp }}$ match exactly, and in turn, the lowest and highest $J_{\text {het }}^{\exp }$ values correspond to frozen fractions between 0 and 1 . In other words, this indicates that any $\Delta a_{\mathrm{w}, \text { het }}$ that falls within the range of our experimental data can be assigned a single $J_{\text {het }}^{\exp }$ value, further corroborating the $a_{\mathrm{w}}$-based approach to describe freezing temperatures and time-dependent kinetics.

We can now use $J_{\text {het }}^{\alpha}(T)$ to reproduce $f$. These results are also given in Figs. 4 and 5 and show overall very good agreement with the experimental data, as indicated by the rootmean-square error (RMSE) being smaller than 0.1 for most cases. $f$ derived by the continuous function $J_{\text {het }}^{\alpha}(T)$ deviates in two cases at low $a_{\mathrm{w}}$ significantly from experimentally derived $f$. This is due to the application of a fitted $\alpha(T)$ curve that results in a continuous $J_{\text {het }}^{\alpha}(T)$. However, $J_{\text {het }}^{\alpha}(T)$ can deviate by half an order of magnitude from experimentally derived $J_{\text {het }}^{\text {exp }}$, depending on the scatter of the data. When calculating and integrating the cumulative $f$, this deviation in $J_{\text {het }}$ at the beginning (high freezing temperatures) propagates through the whole data set, which leads to this apparently lesser fit quality. Again, this is not a problem of the model itself, since $f$ derived from $J_{\text {het }}^{\text {exp }}$ agrees almost perfectly with experimentally derived $f$, but is a matter of how $\alpha(T)$ is fitted. The experimentally derived $f$ do not depend on $J_{\text {het }}$ and on assumptions of the water diffusion coefficient and iceliquid interfacial tension in contrast to application of $J_{\text {het }}^{\alpha}(T)$ to derive $f$.

\subsection{3 $\alpha$-PDF model}

The ice nucleation data are analyzed applying the $\alpha$-PDF model following the studies by Marcolli et al. (2007) and Lüönd et al. (2010). A probability density function (PDF) is applied to distribute $\alpha$ among the IN in the immersed droplets for each investigated $a_{\mathrm{w}} . J_{\text {het }}$ depends on $\alpha$, which in this case is temperature independent. The application of a PDF 

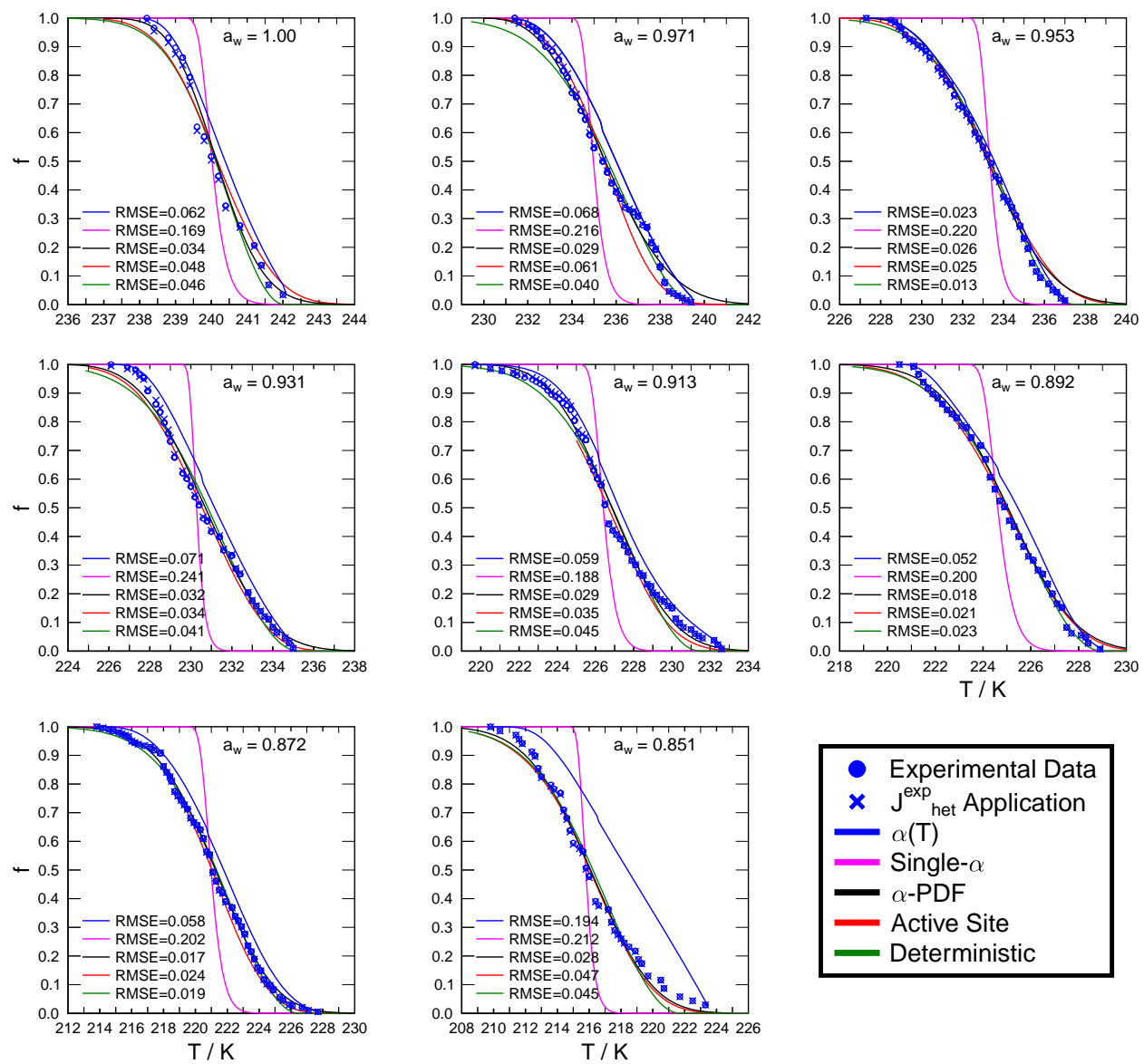

Fig. 4. Summary of different immersion freezing descriptions for water and aqueous $\left(\mathrm{NH}_{4}\right)_{2} \mathrm{SO}_{4}$ droplets containing leonardite as a function of $T$ and $a_{\mathrm{W}}$. The experimentally derived cumulative frozen fraction, $f$, of droplets in $0.2 \mathrm{~K}$ temperature increments is represented by blue circles. Blue crosses indicate application of experimentally derived heterogeneous ice nucleation rate coefficient, $J_{\text {het }}^{\text {exp }}$, to calculate $f$. Blue, magenta, black, red, and green lines represent $\alpha(T)$, single- $\alpha, \alpha$-PDF, active sites, and deterministic model, respectively. The fit quality is given by the root-mean-square error, RMSE.

(Marcolli et al., 2007; Lüönd et al., 2010) and Eq. (9) yield the cumulative $f$ according to

$f(T)=1-\int_{0}^{\pi} p(\alpha) \exp \left[-\frac{\bar{A}}{\mathrm{cr}} \int_{T_{\text {melt }}}^{T^{i}} J_{\text {het }}(T) \mathrm{d} T\right] d \alpha$,

where $p(\alpha)$ represents a log-normal distribution of $\alpha$ for each investigated $a_{\mathrm{w}}$. We follow Marcolli et al. (2007) and describe $p(\alpha)$ as

$p(\alpha)=\frac{1}{\alpha \sigma \sqrt{2 \pi}} \exp \left\{-\frac{[\log \alpha-\mu]^{2}}{2 \sigma^{2}}\right\}$,

where $\alpha, \mu$, and $\sigma$ are obtained by fitting Eq. (10) to the experimental data.

Figures 4 and 5 show the fitted frozen fraction for LEO and PP acting as IN, respectively, when applying the $\alpha$-PDF model for investigated $a_{\mathrm{w}}$. As indicated by the low RMSE values, the fit represents the experimental data very well. This result should come as no surprise since the same data were used to constrain the fit. Figures S4 and S5 show in detail corresponding PDF $p(\alpha)$ for different $a_{\mathrm{w}}$ for ice nucleation from water and aqueous $\left(\mathrm{NH}_{4}\right)_{2} \mathrm{SO}_{4}$ droplets containing LEO and PP, respectively. Tables 3 and 4 list derived fit parameters used for the calculation of $f$ and $\operatorname{PDF} p(\alpha)$ for LEO and PP, respectively.

\subsubsection{Single- $\alpha$ model}

This model is based on the same equations as the $\alpha$-PDF model; however, as outlined by Lüönd et al. (Lüönd et al., $2010)$, in Eq. (10) $p(\alpha)$ is replaced with a delta function, i.e., $p(\alpha)=\delta\left(\alpha=\alpha_{0}\right)$. This procedure assigns all IN the same contact angle, $\alpha_{0}$ instead of a distribution of contact angles.

Figures 4 and 5 show the resulting frozen fractions of droplets containing LEO and PP when applying the single- $\alpha$ model for investigated $a_{\mathrm{w}}$, respectively. The single- $\alpha$ model 

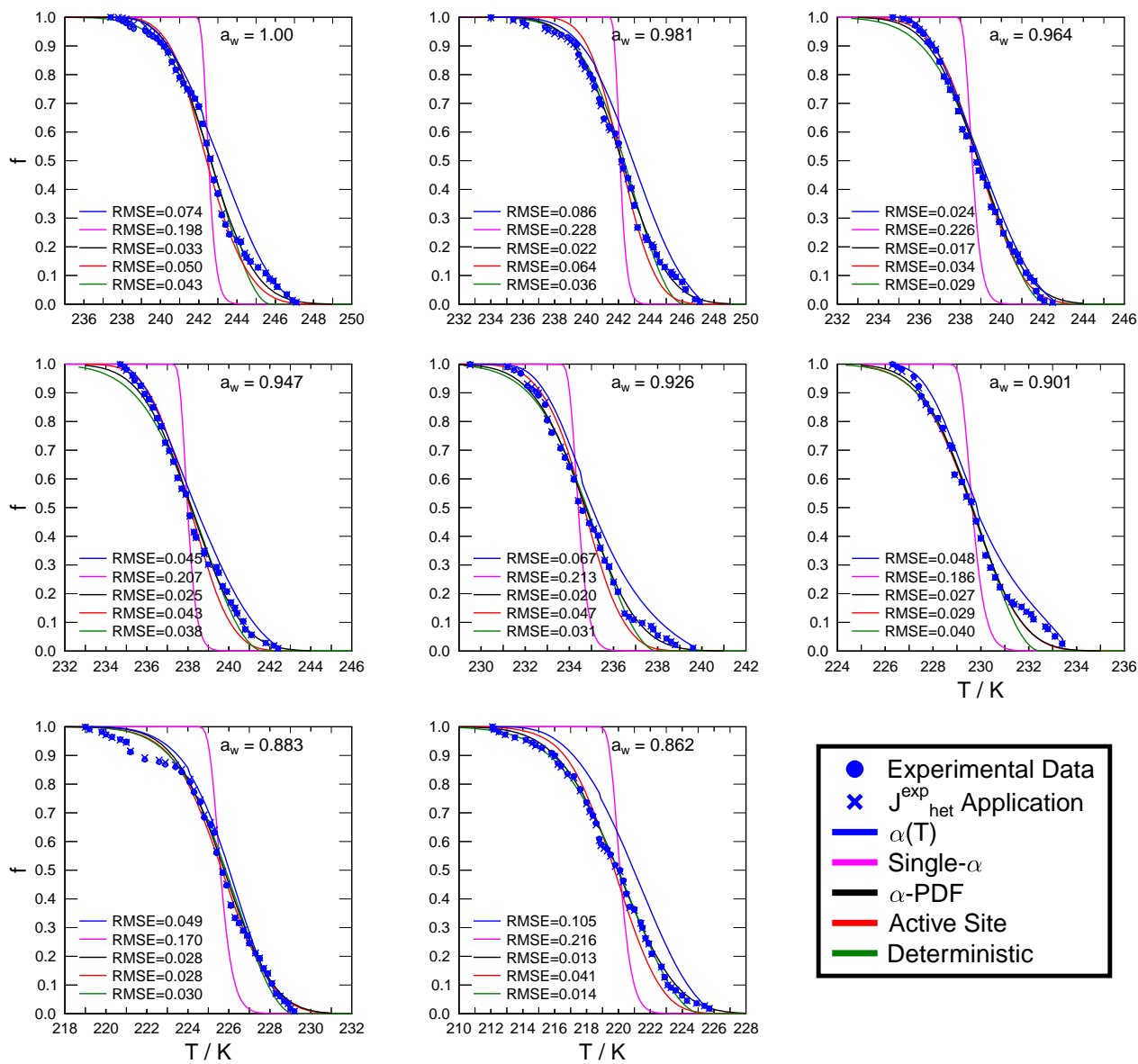

Fig. 5. Summary of different immersion freezing descriptions for water and aqueous $\left(\mathrm{NH}_{4}\right)_{2} \mathrm{SO}_{4}$ droplets containing Pahokee peat as a function of $T$ and $a_{\mathrm{w}}$. The experimentally derived cumulative frozen fraction, $f$, of droplets in $0.2 \mathrm{~K}$ temperature increments is represented by blue circles. Blue crosses indicate application of experimentally derived heterogeneous ice nucleation rate coefficient, $J_{\mathrm{het}}^{\mathrm{exp}}$, to calculate $f$. Blue, magenta, black, red, and green lines represent $\alpha(T)$, single- $\alpha, \alpha$-PDF, active sites, and deterministic model, respectively. The fit quality is given by the RMSE.

does not describe the immersion freezing data well compared to the other descriptions. This is also evident from given RMSE values, which are about 1 order of magnitude higher compared to the other cases. Allowing variation of $\sigma_{\mathrm{sl}}$ could yield a better agreement between the single- $\alpha$ model and the data. However, as mentioned above, this procedure results in $\sigma_{\mathrm{sl}}$ that increases with decreasing temperature, in contrast to measurements and the notion that the supercooled water becomes more ice-like as the temperature decreases (Pruppacher and Klett, 1997; Zobrist et al., 2007). Clearly, a single contact angle attributed to the IN for each investigated solution $a_{\mathrm{w}}$ is not sufficient to represent the ice nucleation data. Tables 3 and 4 list the derived $\alpha_{0}$ used for the calculation of $f$.

\subsubsection{Active sites model}

This ice nucleation description assumes that the surface of an ice nucleus manifests a distribution of varying ice nucleating sites. Ice nucleation occurs only on one of these active sites, where each active site is characterized by one $\alpha$ value and the frequency of occurrence of different active sites is a function of $\alpha$ (Marcolli et al., 2007; Lüönd et al., 2010). The active site surface area is assumed to be similar to the critical ice embryo, about $6 \mathrm{~nm}^{2}$ (Marcolli et al., 2007). Following Marcolli et al. (2007) and Lüönd et al. (2010) we define the frozen fraction as

$f(T)=\frac{1}{N_{\mathrm{tot}}} \sum_{j=1}^{N_{\mathrm{tot}}} p_{\mathrm{frz}, j}(T)$,

where $N_{\text {tot }}$ is the total number of droplets and $p_{\text {frz }, j}(T)$ describes the probability of the $j$-th droplet to freeze accounting for all discretized $\alpha$ values depending on the surface 
density of active sites in each contact angle interval from $\alpha$ to $\alpha+\Delta \alpha$. The probability of one droplet to freeze is

$$
p_{\mathrm{frz}}(T)=1-\prod_{k} \exp \left[\frac{A_{\alpha_{k}}}{\mathrm{cr}} \int_{T_{\text {melt }}}^{T^{i}} J_{\text {het }}\left(T, \alpha_{k}\right) \mathrm{d} T\right],
$$

where $k$ indicates the interval number with an interval size $\Delta \alpha$, and $A_{\alpha_{k}}$ is the total surface area of all active sites with contact angles from $\alpha_{k}$ to $\alpha_{k}+\Delta \alpha$ present in the droplet (Lüönd et al., 2010). The difference to the original formulation is the integration of $J_{\text {het }}(T)$ to account for the changes in $T$ and thus $J_{\text {het }}(T)$ since a constant cooling experiment is conducted.

A Poisson random number with parameter $\lambda_{k}=\rho\left(\alpha_{k}\right) \Delta \alpha \bar{A}$ is sampled to determine the number of sites having a single $\alpha_{k}$ and individually having a surface area of $6 \mathrm{~nm}^{2}$. We assume that the surface site density of active sites with different $\alpha$ can be described for each $a_{\mathrm{w}}$ by (Marcolli et al., 2007)

$\rho(\alpha)=b \exp \left(\frac{-\beta_{1}}{\alpha-\beta_{2}}\right)$,

where $b, \beta_{1}$, and $\beta_{2}$ are fit parameters obtained by fitting the freezing data to a simulation of 1000 droplets applying Eq. (12).

Figures 4 and 5 show the resulting frozen fractions of droplets containing LEO and PP when applying the active site model for investigated $a_{\mathrm{w}}$, respectively. The active site model represents the experimental data very well, as indicated by the low RMSE values. Figures S4 and S5 show in detail corresponding surface site density of active sites, $\rho(\alpha)$, for droplets containing LEO and PP, respectively. Tables 3 and 4 list respective fit parameters used for the calculation of $f$ and $\rho(\alpha)$.

\subsubsection{Deterministic model}

This description assumes that ice nucleation is governed by a characteristic temperature only and fluctuations affecting the ice embryo growth can be neglected (Vali, 1971). This allows us to define a surface density of active sites, $n_{\mathrm{s}}$, nucleating ice between a characteristic temperature and $T_{\text {melt }}$. For each investigated $a_{\mathrm{w}}$ the number of droplets frozen, $N_{\mathrm{f}}$, per temperature interval $\mathrm{d} T$ can then be expressed as (Lüönd et al., 2010)

$$
\frac{\mathrm{d} N_{\mathrm{f}}}{\mathrm{d} T}=\left(N_{\mathrm{tot}}-N_{\mathrm{f}}\right) \bar{A} K^{a_{\mathrm{w}}}\left(T^{i}\right),
$$

where $N_{\text {tot }}$ is the total number of droplets, and $K(T)$ represents the number of ice nucleation events and thus the number of active sites per unit of ice nucleus surface area when cooling the sample by a unit temperature interval (Lüönd et al., 2010; Alpert et al., 2011a,b). The frozen fraction of droplets for each $a_{\mathrm{w}}$ is then derived as

$$
f(T)=1-\exp \left[-\bar{A} n_{\mathrm{S}}\left(T^{i}\right)\right] \text { with } n_{\mathrm{S}}=-\int_{T_{\mathrm{melt}}}^{T^{i}} K(T) \mathrm{d} T
$$

where $n_{\mathrm{S}}$ is expressed as (Connolly et al., 2009; Lüönd et al., 2010)

$n_{\mathrm{s}}=\left\{\begin{array}{ll}a_{1}\left(T-a_{2}\right)^{2} & T<a_{2} \\ =0 & T \geq a_{2}\end{array}\right.$,

where $a_{1}$ and $a_{2}$ are fit parameters.

Figures 4 and 5 show the frozen fractions of droplets containing LEO and PP particles acting as IN when applying the deterministic model, respectively. Similar to the previous models, the deterministic site model represents the experimental data very well as indicated by the small RMSE values. Tables 3 and 4 list corresponding fit parameters used in the deterministic model.

\subsubsection{Discussion on different ice nucleation descriptions}

Five approaches have been applied to analyze immersion freezing of water and aqueous $\left(\mathrm{NH}_{4}\right)_{2} \mathrm{SO}_{4}$ droplets containing LEO and PP. Four are based on CNT and one assumes no time dependence. It should be emphasized that only the $\alpha(T)$-model yields $\alpha$ and $J_{\text {het }}$ values directly from the experimental data; thus, no fitting is involved except if a continuous function of $J_{\text {het }}(T)$ and $f(T)$ is desired. This exercise emphasizes three points that are different to the commonly applied nucleation descriptions ( $\alpha$-PDF, active sites, and deterministic) that are fitted to the frozen fraction. First, as previously stated, no fitting is involved and no free parameters are available for the calculation of $J_{\text {het }}(T)$ from Eq. (2). Only experimental data - i.e., number of freezing events, nucleation time, and available IN surface areas - are employed (Zobrist et al., 2007). Second, $J_{\text {het }}(T)$ is independent of the frozen fraction and is only a function of $T$. Thus, $f$ given in Figs. 4 and 5 is not described by a single $J_{\text {het }}$ value. Each investigated temperature interval possesses one $J_{\text {het }}$ value (Zobrist et al., 2007; Knopf and Forrester, 2011; Alpert et al., $2011 \mathrm{a}, \mathrm{b})$. Once $J_{\text {het }}$ for a particular temperature is derived, the number of frozen droplets is calculated by knowledge of available IN surface areas and nucleation time. Third, $\alpha(T)$ can be applied to determine $J_{\text {het }}$ for given freezing temperatures (within the laboratory-probed temperature range) and then used to calculate the number of frozen droplets for conditions (i.e., $A$ and $t$ ) different than the ones applied in the laboratory.

Figures 4 and 5 show clearly that the single- $\alpha$ model, possessing only one free-fit parameter, is the least representative description of the experimentally derived frozen fractions. $\alpha(T), \alpha$-PDF, active sites, and deterministic model represent measured frozen fractions equally well overall; neither description is significantly superior over the other when 

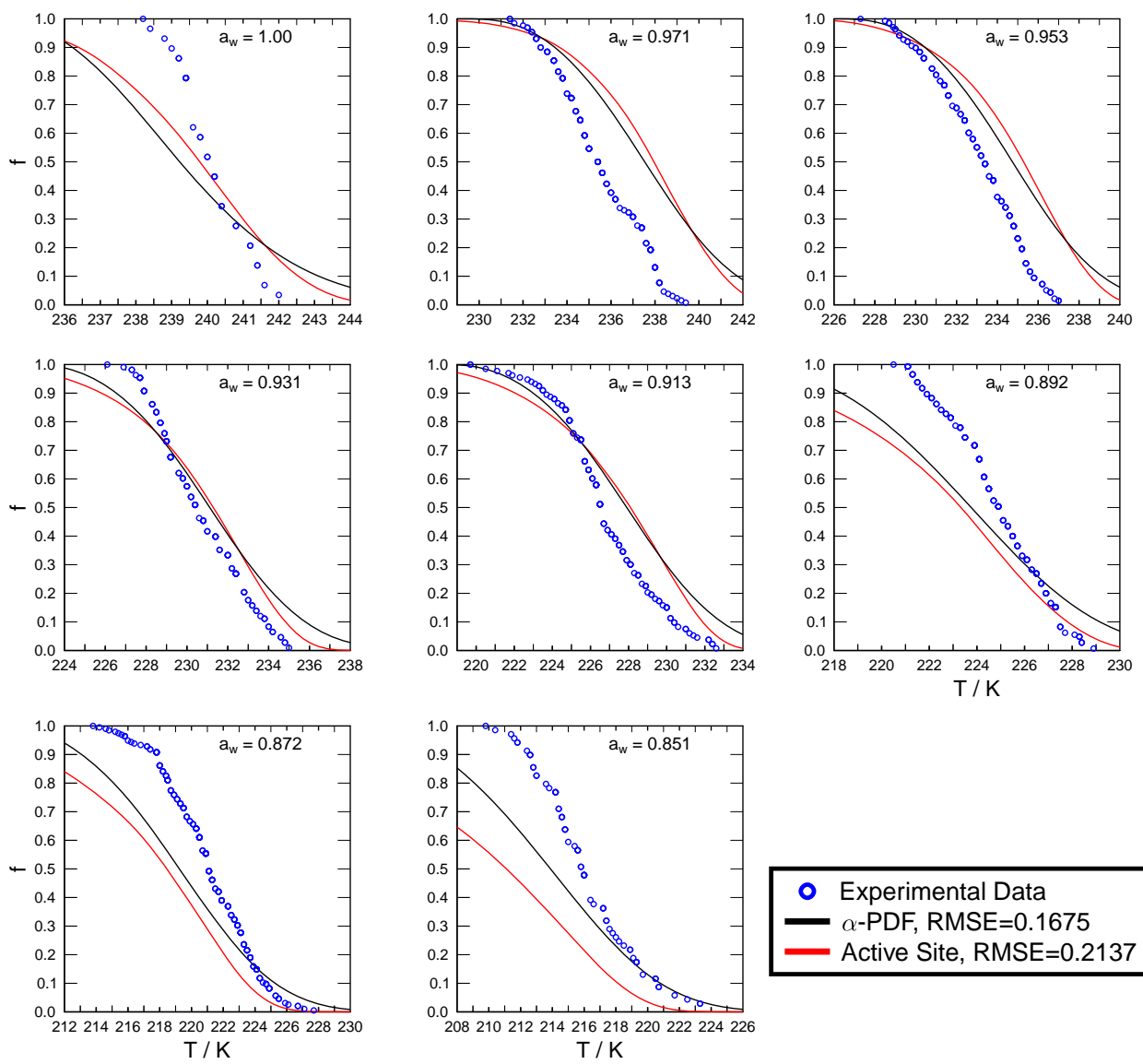

Fig. 6. Resulting immersion freezing descriptions for water and aqueous $\left(\mathrm{NH}_{4}\right)_{2} \mathrm{SO}_{4}$ droplets containing leonardite when fitting the entire immersion freezing data set including all investigated $a_{\mathrm{w}}$ using $\alpha$-PDF (black lines) and active sites parameterizations (red lines). The experimentally derived cumulative frozen fraction, $f$, of droplets in $0.2 \mathrm{~K}$ temperature increments is represented by blue circles. The fit quality is given by the RMSE.

representing the frozen fraction, and thus the underlying nucleation mechanism and nature of the ice nucleating sites cannot be inferred. The very similar representation quality of the fit-based ice nucleation descriptions $\alpha$-PDF, active sites, and deterministic model is due to the application of fitting functions with sufficient free-fit parameters to reproduce the same data set to which they are fitted. In other words, fitting experimentally observed frozen fractions of droplets by these different fit-based nucleation descriptions neither yields the underlying nucleation mechanism nor the nature and distribution of the ice nucleating sites. The $\alpha(T)$-model differs in that that a physical theory is tested by experimental data and only $\alpha$ is fitted with respect to $T$ to yield $J_{\text {het }}^{\alpha}$ in order to derive continuous cumulative $f$. Corresponding $J_{\text {het }}^{\text {exp }}$ and $J_{\text {het }}^{\alpha}$ can be applied only in the investigated temperature range, but we emphasize that investigated nucleation time and IN surface areas can lie outside of our laboratory scales.

Figures 2 to 5 and Tables 3 and 4 indicate that for each IN and $a_{\mathrm{w}}$, the underlying investigated fitting parameters for application of each nucleation description differ significantly.
The reason for this is most likely due to the solute effect on ice nucleation and potential interaction of the solute with the IN surfaces impacting the hydrogen bonding network (Zobrist et al., 2003; Knopf and Rigg, 2011; Alpert et al., 2011b). From this it follows that it would be computationally cumbersome and demanding to represent in a single parameterization all parameters to describe immersion freezing for one IN type for typical atmospheric $T$ and $\mathrm{RH}$.

To further test the applicability of the $\alpha-\mathrm{PDF}$, as well as active sites parameterizations, we fit our entire frozen fraction data set spanning all investigated $a_{\mathrm{w}}$ yielding one parameter set for each model. This is to test the common notion that the resulting fit parameters potentially represent particle properties that should not depend on varying temperature, IN surface area, and $a_{\mathrm{w}}$. Figures 6 and 7 show $\alpha$-PDF and active sites fit parameterizations in comparison with experimentally determined $f$ for LEO and PP, respectively. Corresponding fit parameters are given in Table 5. Overall, the fit performance is significantly poorer compared to the case of fitting $f$ for individual $a_{\mathrm{w}}$ immersion freezing data sets, as 

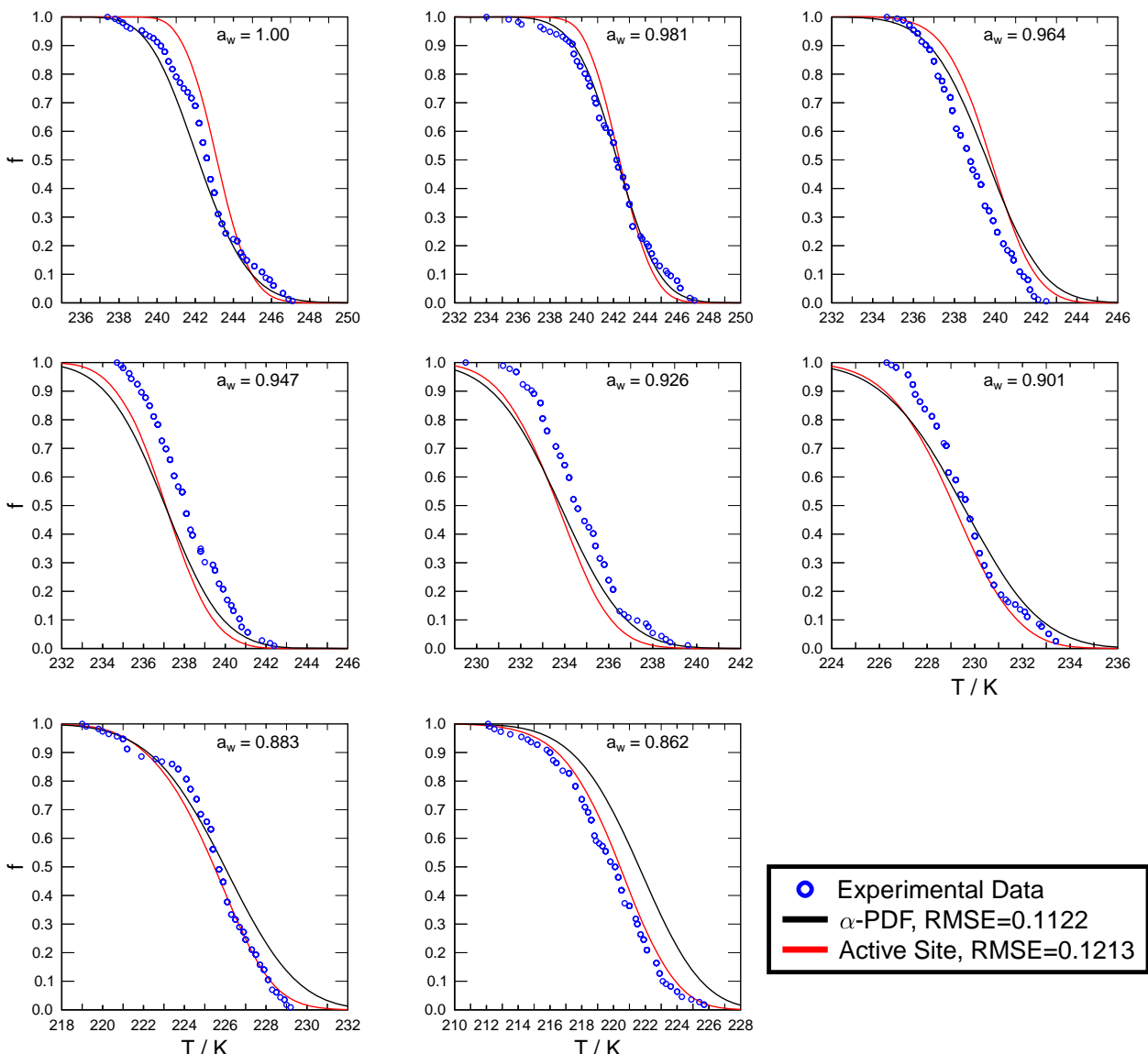

Fig. 7. Resulting immersion freezing descriptions for water and aqueous $\left(\mathrm{NH}_{4}\right)_{2} \mathrm{SO}_{4}$ droplets containing Pahokee peat when fitting the entire immersion freezing data set including all investigated $a_{\mathrm{W}}$ using $\alpha$-PDF (black lines) and active sites parameterizations (red lines). The experimentally derived cumulative frozen fraction, $f$, of droplets in $0.2 \mathrm{~K}$ temperature increments is represented by blue circles. The fit quality is given by the RMSE.

indicated by the RMSE values being larger by up to about 1 order of magnitude. This could have been anticipated from Tables 3 and 4 and Figs. S4 and S5 indicating a large variation of the fit parameters with respect to $a_{\mathrm{w}}$ to achieve an overall good fit. In some instances where the fit parameters for all data sets are somehow similar to the fit parameters derived from $f$ at a given single $a_{\mathrm{w}}$, the fits come closer to the experimental data sets. In most instances the fits deviate significantly from experimentally derived $f$, as shown in Figs. 6 and 7. Figure 8 presents the PDF $p(\alpha)$ and active sites surface density for LEO and PP when fitting all available data sets at once. These distributions may reflect a sort of average distribution from those derived from fitting $f$ determined at single $a_{\mathrm{w}}$. Clearly, these results corroborate our findings discussed above that current fit-based parameterizations cannot capture immersion freezing occurring from aqueous solutions and thus at subsaturated conditions. Furthermore, this also strongly suggests that derived fit parameters do not represent fundamental particle properties. An elegant solution to
Table 5. Fit parameters for $\alpha$-PDF and active sites descriptions when fitting entire immersion freezing data sets including all investigated water activities for water and aqueous ammonium sulfate droplets containing leonardite and Pahokee peat.

\begin{tabular}{llrr}
\hline Model & Parameter & Leonardite & Pahokee peat \\
\hline \multirow{4}{*}{$\alpha$-PDF } & $\alpha\left[^{\circ}\right]$ & 94.7260 & 85.0635 \\
& $\mu$ & 0.5028 & 0.3952 \\
& $\sigma$ & 0.1210 & 0.0797 \\
& & & \\
Active Sites & $\beta_{1} \times 10^{7}\left[\mathrm{~cm}^{-2}\right]$ & 3.1975 & 28.727 \\
& $\beta_{2}$ & 0.2736 & 0.9279 \\
& & 1.0566 & 0.9313 \\
\hline
\end{tabular}

this problem is provided by a water-activity-based model of immersion freezing (Knopf and Alpert, 2013). 

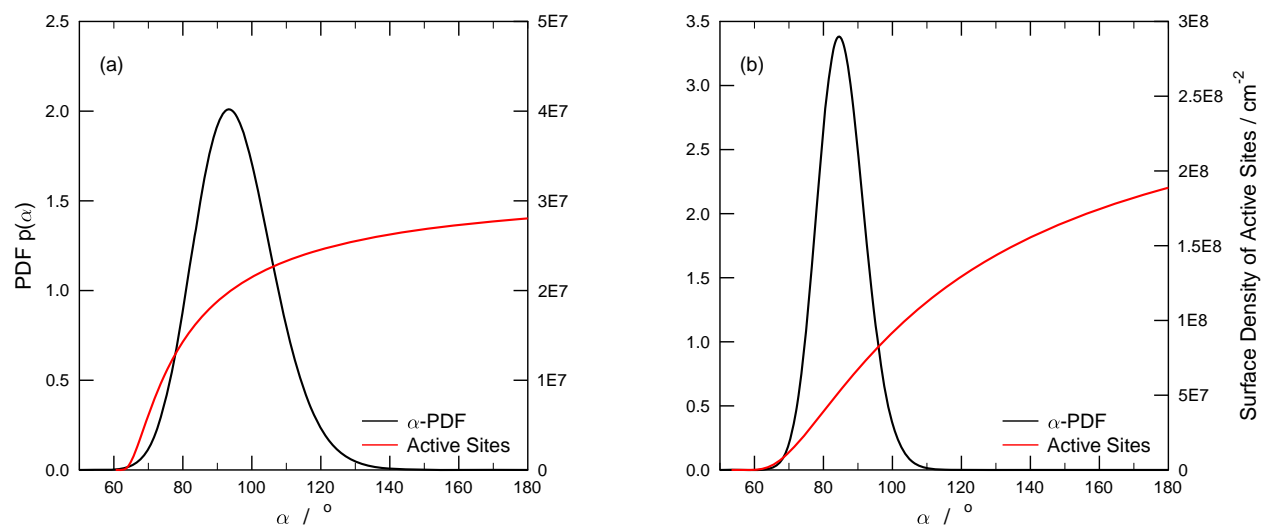

Fig. 8. Lognormal PDF $p(\alpha)$ (black line) and surface density of active sites distribution (red line) determined from immersion freezing data sets for all investigated $a_{\mathrm{W}}$ for water and aqueous $\left(\mathrm{NH}_{4}\right)_{2} \mathrm{SO}_{4}$ droplets containing leonardite (a) and Pahokee peat (b). Note the different scales in panels (a) and (b).

\section{Atmospheric implications}

The freezing data shown in Fig. 1 indicates that HULIS compounds possess the potential to act as immersion IN enhancing the freezing temperatures by $5-15 \mathrm{~K}$ compared to homogeneous ice nucleation over a wide range of RH. The heterogeneous freezing temperatures can be well described by an ice melting curve shifted by $\Delta a_{\mathrm{w}, \text { het }}=0.2703$ and 0.2466 for water and aqueous $\left(\mathrm{NH}_{4}\right)_{4} \mathrm{SO}_{4}$ droplets containing LEO and PP particles, respectively. It has been previously shown that immersion freezing temperatures elevated by only 1.8 to $5 \mathrm{~K}$ compared to homogeneous ice nucleation due to the presence of oxalic acid dihydrate crystals, translating into $\Delta a_{\mathrm{w}, \text { het }}$ $=0.285$, can have significant effects on the global radiative forcing due to alteration of the microphysical and thus radiative properties of cirrus clouds (Zobrist et al., 2006; Kärcher and Lohmann, 2003). Since HULIS can be a common compound of ubiquitous organic aerosol, our results indicate that these particles can also play a significant role in atmospheric glaciation processes and consequently the radiative budget.

This study corroborates previous work showing that immersion freezing temperatures can be well described by an $a_{\mathrm{w}}$-based nucleation description (Zuberi et al., 2002; Archuleta et al., 2005; Cantrell and Robinson, 2006; Zobrist et al., 2008; Koop and Zobrist, 2009; Knopf et al., 2011; Knopf and Rigg, 2011; Alpert et al., 2011a,b). Previously determined $\Delta a_{\mathrm{w}}$ for different IN including organic, inorganic, and biological particles immersed in various aqueous solutions are given in Table 6 . The smaller $\Delta a_{\mathrm{w}}$, the higher the ice nucleation potential. As can be seen from Table 6, LEO and PP show similar ice nucleation efficiencies compared to other organic, inorganic, and biological IN. However, it has been shown previously, employing water droplets, that the immersion freezing temperature increases when IN surface areas increase (Zobrist et al., 2007; Lüönd et al., 2010; Knopf and Forrester, 2011; Murray et al., 2011; Broadley et al., 2012;
Pinti et al., 2012; Knopf and Alpert, 2013). Therefore, when comparing $\Delta a_{\mathrm{w}}$, the applied total IN surface areas should be taken into account.

As discussed above, the kinetic analysis of the frozen fractions by fit-based nucleation descriptions does not allow for inference of the underlying nucleation mechanism. This is supported by (i) the very similar fit quality of $\alpha$-PDF, active sites, and deterministic descriptions; (ii) application of different water activities result in different fit parameters; and (iii) fitting the entire immersion freezing data set including all investigated $a_{\mathrm{w}}$ using $\alpha$-PDF and active sites parameterizations does not yield satisfactory representation of the frozen fraction. It is clear from above analyses that if immersion freezing is time dependent (CNT) (Welti et al., 2012; Knopf and Alpert, 2013), then parameterizations fitted to laboratorymeasured frozen fractions cannot be applied to atmospheric conditions since experimental timescales can differ by orders of magnitude from atmospheric timescales (Westbrook and Illingworth, 2013), and atmospheric IN surface areas are likely not the same as applied in laboratory experiments (Ervens and Feingold, 2012). This is because fitting frozen fractions by a least-squares minimization procedure always results in the fit being constrained by the laboratory-derived data. The corresponding fit parameters are consequently only valid for the specific data set, thereby discarding the potential of exploiting the underlying physical processes expressed as $J_{\text {het }}$. This is in contrast to the $\alpha(T)$-model, which initially derives $J_{\text {het }}^{\text {exp }}$ and then provides a physical explanation in the form of contact angle distribution. At a given freezing temperature, $J_{\text {het }}$ in combination with $A$ and $t$ yields the frozen fraction or ice particle numbers.

Our experimental approach allows for derivation of ice nucleation kinetics for a range of droplet solution $a_{\mathrm{w}}$ in addition to freezing temperatures. Atmospherically relevant ice particle production rates, $P_{\text {ice }}(T, \mathrm{RH})$, can be derived by using the $\alpha(T)$-model since it allows for application to 
Table 6. Water activity shift from the ice melting curve, $\Delta a_{\mathrm{W}}$, for various immersion ice nuclei in different aqueous solutions. Approximate estimates of the ice nucleus surface area (order of magnitude) are also given for comparison. LEO: leonardite, PP: Pahokee Peat, ND: 1-nonadecanol, HD: 1-heptadecanol, OAD: oxalic acid dihydrate, KA: kaolinite, MO: montmorillonite, ATD: Arizona test dust, $\mathrm{Al}_{2} \mathrm{O}_{3}$ : aluminum oxide, AgI: silver iodide, $\mathrm{SiO}_{2}$ : silica spheres, SM: Snowmax, T.P.: Thalassiosira pseudonana, N.A.: Nannochloris atomus, E.B.: Eleodes blanchardi, I.A.: Ips acuminatus, R.S.: Rhabdophaga strobiloides, and B.C.: Bracon cephi.

\begin{tabular}{llll}
\hline Ice nuclei & IN surface area $\left[\mathrm{cm}^{2}\right]$ & $\Delta a \mathrm{w}$ & Reference \\
\hline $\mathrm{LEO}$ & $8 \times 10^{-7}$ & 0.2703 & this study \\
$\mathrm{PP}$ & $1 \times 10^{-6}$ & 0.2466 & this study \\
$\mathrm{ND}$ & $6 \times 10^{-2}$ & 0.098 & Knopf and Forrester (2011) \\
$\mathrm{ND}$ & $8 \times 10^{-2}$ & 0.100 & Zobrist et al. (2008) \\
$\mathrm{HD}$ & $1 \times 10^{-1}$ & 0.135 & Cantrell and Robinson (2006) \\
$\mathrm{OAD}$ & $<4 \times 10^{-12 \mathrm{a}}$ & 0.285 & Zobrist et al. (2006) \\
$\mathrm{KA}$ and MO & $9 \times 10^{-7 \mathrm{~b}}$ & 0.242 & Zuberi et al. (2002) \\
$\mathrm{ATD}$ & $5 \times 10^{-6 \mathrm{c}}$ & 0.195 & Zobrist et al. (2008) \\
$\mathrm{ATD}$ & $5 \times 10^{-6 \mathrm{c}}$ & 0.209 & Koop and Zobrist (2009) \\
$\mathrm{Al}_{2} \mathrm{O}_{3}$ & $1 \times 10^{-9 \mathrm{~d}}$ & 0.250 & Archuleta et al. (2005) \\
$\mathrm{SiO}{ }_{2}$ & $1^{\mathrm{e}}$ & 0.173 & Zobrist et al. (2008) \\
$\mathrm{AgI}$ & $8 \times 10^{-4 \mathrm{f}}$ & 0.181 & Zobrist et al. (2008) \\
$\mathrm{SM}$ & $4 \times 10^{-8 \mathrm{~g}}$ & 0.088 & Koop and Zobrist (2009) \\
$\mathrm{T} . P$. & $1 \times 10^{-6}$ & 0.2303 & Alpert et al. (2011a) \\
$\mathrm{N} . \mathrm{A}$. & $1.3 \times 10^{-5}$ & 0.2391 & Alpert et al. (2011b) \\
E.B. & unknown $^{\mathrm{h}}$ & 0.048 & Lee et al. (1981) \\
$\mathrm{I} . \mathrm{A}$. & unknown $^{\mathrm{i}}$ & 0.177 & Lee et al. (1984) \\
$\mathrm{R}$.S. & unknown $^{\mathrm{j}}$ & 0.223 & Miller (1982) \\
B.C. & unknown $^{\mathrm{k}}$ & 0.241 & Salt (1959) \\
\hline
\end{tabular}

a Assuming $4 \mathrm{wt} \%$ oxalic acid content in $4 \mu \mathrm{m}$ sized droplet and precipitated as solid spherical particle.

b Assuming 3 spherical dust particles $3 \mu \mathrm{m}$ in diameter per droplet.

${ }^{\mathrm{c}}$ Assuming $5 \mathrm{wt} \%$ ATD aqueous solution and ATD particle diameter of $1.5 \mu \mathrm{m}$.

d Assuming spherical particles $200 \mathrm{~nm}$ in diameter.

e Assuming $0.47 \mathrm{wt} \% \mathrm{SiO}_{2}$ aqueous solution and spherical particles $90 \mathrm{~nm}$ in diameter.

${ }^{\mathrm{f}}$ Assuming diluted $1.64 \mathrm{wt} \% \mathrm{AgNO}_{3}$ aqueous solution and droplet sizes $3 \mu \mathrm{m}$ in diameter.

$\mathrm{g}$ Assuming 1 bacterium per droplet. Only outer shell (Morris et al., 2004) of bacteria considered as ice nucleating substrate.

${ }^{\mathrm{h}}$ Hemolymph containing unknown IN was withdrawn from the leg of beetle Eleodes blanchardi.

Hemolymph accounted for $5 \%(\mathrm{v} / \mathrm{v})$ of aqueous organic solution.

${ }^{\mathrm{i}}$ Hemolymph containing unknown IN was withdrawn from beetle Ips acuminatus.

j Hemolymph containing unknown IN was withdrawn from willow gall larvae Rhabdophaga strobiloides.

${ }^{\mathrm{k}}$ Hemolymph containing unknown IN was withdrawn from larvae Bracon cephi.

atmospheric timescales and IN surface areas. Corresponding $J_{\text {het }}^{\alpha}\left(T, \mathrm{a}_{\mathrm{w}}=\mathrm{RH}\right)$, assuming equilibrium, are then used to derive $P_{\text {ice }}(T, \mathrm{RH})=J_{\text {het }}^{\alpha}\left(T, a_{\mathrm{w}}=\mathrm{RH}\right) \cdot A$. Furthermore, $J_{\text {het }}^{\alpha}\left(T, a_{\mathrm{w}}=\mathrm{RH}\right)$, as outlined above, allows for calculation of the frozen fractions along an air parcel trajectory when knowing initial number of unfrozen droplets, $T$, and $\mathrm{RH}$. Ice particle numbers, $N_{\text {ice }}(T, \mathrm{RH})$, can be calculated for given ice activation time periods according to $N_{\text {ice }}(T, \mathrm{RH})=$ $J_{\text {het }}^{\alpha}\left(T, a_{\mathrm{w}}=\mathrm{RH}\right) \cdot A \cdot t$. Application of $J_{\text {het }}^{\alpha}\left(T, a_{\mathrm{w}}\right)$ is only valid in the experimentally probed temperature range; however, $A$ and $t$ can constitute any value. A similar process to calculate $P_{\text {ice }}$ and $N_{\text {ice }}$ can be applied to $\alpha$-PDF, active sites, and deterministic descriptions using Eqs. (10), (12), and (16), if atmospheric conditions are similar to the experimental conditions with regard to time and IN surface area.

Immersion freezing by LEO and PP can also be implemented within a cloud-resolving model, making use of the
$a_{\mathrm{w}}(=\mathrm{RH})$ dependency of $J_{\text {het }}$ similar to the $a_{\mathrm{W}}$-based homogeneous ice nucleation description (Koop et al., 2000; Koop and Zobrist, 2009). This is based on the fact that experimentally derived $J_{\text {het }}$ is relatively constant along the $a_{\mathrm{w}}$-based freezing curve. The relationship of $J_{\text {het }}$ and $a_{\mathrm{w}}$ allows for calculation of ambient $f(T, \mathrm{RH})$ and $N_{\text {ice }}(T, \mathrm{RH})$ for given ice nucleation time, independent of the nature of the solute, by knowledge of environmental RH and IN surface areas. However, the presented analysis lacks the dependence of $J_{\text {het }}$

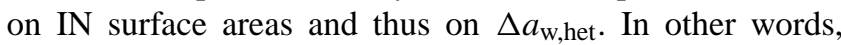
the slope of $J_{\text {het }}$ as a function of $\Delta a_{\mathrm{w} \text {,het }}$ was not inferred in this study. As described in detail in Knopf and Forrester (2011), $\tilde{T}_{\mathrm{f}}$ and $J_{\text {het }}$ have to be measured as a function of

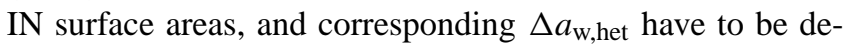
termined. This is discussed in a separate publication (Knopf and Alpert, 2013) and is beyond the scope of this study. Despite this shortcoming, we can apply our results to estimate 
ice particle production rates from HULIS compounds. Following a recent study by Konovalov et al. (2012), who estimated particle-surface-bound HULIS compounds to assess light-induced ozone loss, we use, for this example, their estimate that $14 \%$ of the total particle population surface area consists of HULIS and assume an average aerosol surface area of $5000 \mathrm{~mm}^{2} \mathrm{~cm}^{-3}$. The corresponding HULIS surface area is about $7 \times 10^{-6} \mathrm{~cm}^{2}$ and compares well with our employed IN surface areas. Using $J_{\text {het }}^{\exp }\left(\tilde{T}_{\mathrm{f}}\right)=(9.6 \pm 2.5) \times 10^{4}$ and $(5.4 \pm 1.4) \times 10^{4} \mathrm{~cm}^{-2} \mathrm{~s}^{-1}$, this yields $P_{\text {ice }}(T, \mathrm{RH})$ of 0.67 and 0.38 ice particles per $\mathrm{cm}^{3}$ air per second for LEO and PP acting as IN, respectively, for $T$ and RH given by the corresponding freezing curves. Similarly, following Eqs. (68 ) the frozen fraction can be derived when total droplet numbers, cloud activation times, and IN surface areas are known.

\section{Conclusions}

Immersion freezing of water and aqueous $\left(\mathrm{NH}_{4}\right)_{4} \mathrm{SO}_{4}$ droplets containing leonardite and Pahokee peat particles acting as IN has been investigated for temperatures as low as $215 \mathrm{~K}$ and solution water activity from 0.85 to 1.0 . Leonardite and Pahokee peat particles can act as efficient IN in the immersion mode by increasing the freezing temperature by about $5-15 \mathrm{~K}$ compared to homogeneous ice nucleation. Freezing temperatures follow a water-activity-based nucleation description. This allows for predictions of freezing temperatures using RH without knowledge of the solute. The immersion freezing curve for water and aqueous $\left(\mathrm{NH}_{4}\right)_{4} \mathrm{SO}_{4}$ droplets containing leonardite and Pahokee peat particles can be parameterized as a function of water activity (which equals RH under equilibrium conditions) and temperature by a shift in water activity of 0.2703 and 0.2466 of the ice melting curve, respectively. Similar to the water-activitybased homogeneous ice nucleation description (Koop et al., 2000), heterogeneous ice nucleation rate coefficients, corresponding to the freezing curves representing median freezing temperatures, are constant and yield $(9.6 \pm 2.5) \times 10^{4}$ and $(5.4 \pm 1.4) \times 10^{4} \mathrm{~cm}^{-2} \mathrm{~s}^{-1}$ for leonardite and Pahokee peat particles, respectively. Thus, the parameterized freezing curves and corresponding heterogeneous ice nucleation coefficient values can be employed in atmospheric models to predict freezing temperatures, frozen fractions, ice particle production rates, and ice particle numbers for given cloud activation times when IN surface areas and relative humidity are known.

Assuming one contact angle for each ice nucleus as a function of temperature yields heterogeneous ice nucleation rate coefficients that allow reproduction of experimentally measured frozen fractions. Application of a single contact angle for the entire IN population does not represent the observed frozen fractions well. Assuming a probability density distribution of contact angles, active sites distribution, and deterministic approach results in equally good represen- tations of measured frozen fractions of droplets. This implies that the underlying ice nucleation mechanism, i.e., classical nucleation theory versus a time-independent process, cannot be discriminated from fitting experimentally derived frozen fractions. This is in contrast to previous studies focusing on immersion freezing from pure-water droplets that can discriminate one optimal fit-based freezing description (Lüönd et al., 2010; Welti et al., 2012). When using a single parameterization of a probability density distribution of contact angles or active sites distribution to fit all individual $a_{\mathrm{w}}$ immersion freezing data simultaneously, frozen fraction curves are not reproduced. This implies that these formulations cannot be applied to immersion freezing of aqueous solutions, and suggests that derived fit parameters do not represent independent particle properties. Furthermore, one must be careful when choosing to apply these approaches to other atmospherically relevant conditions than that of the measurements. However, the very good prediction of freezing temperature and kinetics by the water-activity-based nucleation description similar to the case of homogenous ice nucleation strongly supports that the underlying ice nucleation mechanism is governed by a time- and surface-area-dependent nucleation process. Derived heterogeneous ice nucleation rate coefficients can be directly applied to atmospheric conditions since differences in cloud activation and experimental timescales and IN surface areas are implicitly accounted for by the ice nucleation rate coefficient instead of the frozen fraction.

\section{Supplementary material related to this article is available online at: http://www.atmos-chem-phys.net/13/ 6603/2013/acp-13-6603-2013-supplement.pdf.}

Acknowledgements. Y. J. Rigg acknowledges support from NSF Division of Human Resource Development State University of New York Louis Stokes Alliance for Minority Participation Bridge to the Doctorate Program. This research was supported by the NOAA Climate Program Office, Atmospheric Composition and Climate Program, grant NA08OAR4310545, and by the Office of Science (BER), U.S. Department of Energy.

Edited by: M. Ammann

\section{References}

Alpert, P. A., Aller, J. Y., and Knopf, D. A.: Ice nucleation from aqueous $\mathrm{NaCl}$ droplets with and without marine diatoms, Atmos. Chem. Phys., 11, 5539-5555, doi:10.5194/acp-11-55392011, 2011a.

Alpert, P. A., Aller, J. Y., and Knopf, D. A.: Initiation of the ice phase by marine biogenic surfaces in supersaturated gas and supercooled aqueous phases, Phys. Chem. Chem. Phys., 13, 19882-19894, doi:10.1039/c1cp21844a, 2011b. 
Ansmann, A., Tesche, M., Althausen, D., Mueller, D., Seifert, P., Freudenthaler, V., Heese, B., Wiegner, M., Pisani, G., Knippertz, P., and Dubovik, O.: Influence of Saharan dust on cloud glaciation in southern Morocco during the Saharan Mineral Dust Experiment, J. Geophys. Res., 113, D04210, doi:10.1029/2007JD008785, 2008.

Archuleta, C. M., DeMott, P. J., and Kreidenweis, S. M.: Ice nucleation by surrogates for atmospheric mineral dust and mineral dust/sulfate particles at cirrus temperatures, Atmos. Chem. Phys., 5, 2617-2634, doi:10.5194/acp-5-2617-2005, 2005.

Baker, M. B.: Cloud microphysics and climate, Science, 276, 10721078, 1997.

Baker, M. B. and Peter, T.: Small-scale cloud processes and climate, Nature, 451, 299-300, 2008.

Baustian, K. J., Cziczo, D. J., Wise, M. E., Pratt, K. A., Kulkarni, G., Hallar, A. G., and Tolbert, M. A.: Importance of aerosol composition, mixing state, and morphology for heterogeneous ice nucleation: a combined field and laboratory approach, J. Geophys. Res., 117, D06217, doi:10.1029/2011JD016784, 2012.

Bertram, A. K., Koop, T., Molina, L. T., and Molina, M. J.: Ice formation in $\left(\mathrm{NH}_{4}\right)_{2} \mathrm{SO}_{4}-\mathrm{H}_{2} \mathrm{O}$ particles, J. Phys. Chem. A, 104, 584-588, 2000.

Broadley, S. L., Murray, B. J., Herbert, R. J., Atkinson, J. D., Dobbie, S., Malkin, T. L., Condliffe, E., and Neve, L.: Immersion mode heterogeneous ice nucleation by an illite rich powder representative of atmospheric mineral dust, Atmos. Chem. Phys., 12, 287-307, doi:10.5194/acp-12-287-2012, 2012.

Brunauer, S., Emmett, P., and Teller, E.: Adsorption of gases in multimolecular layers, J. Am. Chem. Soc., 60, 309-319, doi:10.1021/ja01269a023, 1938.

Cantrell, W. and Heymsfield, A.: Production of ice in tropospheric clouds - a review, B. Am. Meteorol. Soc., 86, 795-807, doi:10.1175/BAMS-86-6-795, 2005.

Cantrell, W. and Robinson, C.: Heterogeneous freezing of ammonium sulfate and sodium chloride solutions by long chain alcohols, Geophys. Res. Lett., 33, L07802, doi:10.1029/2005g1024945, 2006.

Chan, M. N. and Chan, C. K.: Hygroscopic properties of two model humic-like substances and their mixtures with inorganics of atmospheric importance, Environ. Sci. Technol., 37, 5109-5115, 2003.

Chen, T., Rossow, W. B., and Zhang, Y. C.: Radiative effects of cloud-type variations, Tellus A, 50, 259-264, 2000.

Chen, Y., Kreidenweis, S. M., McInnes, L. M., Rogers, D. C., and DeMott, P. J.: Single particle analyses of ice nucleating aerosols in the upper troposphere and lower stratosphere, Geophys. Res. Lett., 25, 1391-1394, 1998.

Clegg, S. L., Brimblecombe, P., and Wexler, A. S.: A thermodynamic model of the system $\mathrm{H}^{+}-\mathrm{NH}_{4}^{+}-\mathrm{Na}^{+}-\mathrm{SO}_{4}^{2-}-\mathrm{NO}_{3}^{-}-\mathrm{Cl}^{-}-$ $\mathrm{H}_{2} \mathrm{O}$ at $298.15 \mathrm{~K}$, J. Phys. Chem. A, 102, 2155-2171, available at: http://www.aim.env.uea.ac.uk/aim/aim.php (last access: March 2013), 1998.

Connolly, P. J., Möhler, O., Field, P. R., Saathoff, H., Burgess, R., Choularton, T., and Gallagher, M.: Studies of heterogeneous freezing by three different desert dust samples, Atmos. Chem. Phys., 9, 2805-2824, doi:10.5194/acp-9-2805-2009, 2009.

Cziczo, D. J., Murphy, D. M., Hudson, P. K., and Thomson, D. S.: Single particle measurements of the chemical composition of cirrus ice residue during CRYSTAL-FACE, J. Geophys. Res., 109,
D04201, doi:10.1029/2003JD004032, 2004.

DeMott, P. J., Rogers, D. C., Kreidenweis, S. M., Chen, Y., Twohy, C. H., Baumgardner, D., Heymsfield, A. J., and Chan, K. R.: The role of heterogeneous freezing in upper tropospheric clouds: inferences from SUCCESS, Geophys. Res. Lett., 25, 1387-1390, 1998.

DeMott, P. J., Sassen, K., Poellot, M. R., Baumgardner, D., Rogers, D. C., Brooks, S. D., Prenni, A. J., and Kreidenweis, S. M.: African dust aerosols as atmospheric ice nuclei, Geophys. Res. Lett., 30, 1732, doi:10.1029/2003GL017410, 2003.

Ervens, B. and Feingold, G.: On the representation of immersion and condensation freezing in cloud models using different nucleation schemes, Atmos. Chem. Phys., 12, 5807-5826, doi:10.5194/acp-12-5807-2012, 2012.

Fornea, A. P., Brooks, S. D., Dooley, J. B., and Saha, A.: Heterogeneous freezing of ice on atmospheric aerosols containing ash, soot, and soil, J. Geophys. Res., 114, D13201, doi:10.1029/2009jd011958, 2009.

Forster, P., Ramaswamy, V., Artaxo, P., Berntsen, T., Betts, R., Fahey, D. W., Haywood, J., Lean, J., Lowe, D. C., Myhre, G., Nganga, J., Prinn, R., Raga, G., Schulz, M., and Van Dorland, R.: Changes in Atmospheric Constituents and in Radiative Forcing, chap. 2, Cambridge University Press, Cambridge, UK and New York, NY, USA, 131-234, 2007.

Fromm, M., Lindsey, D. T., Servranckx, R., Yue, G., Trickl, T., Sica, R., Doucet, P., and Godin-Beekmann, S. E.: The untold story of pyrocumulonimbus, B. Am. Meteorol. Soc., 91, 11931209, doi:10.1175/2010BAMS3004.1, 2010.

Froyd, K. D., Murphy, D. M., Lawson, P., Baumgardner, D., and Herman, R. L.: Aerosols that form subvisible cirrus at the tropical tropopause, Atmos. Chem. Phys., 10, 209-218, doi:10.5194/acp10-209-2010, 2010.

Graber, E. R. and Rudich, Y.: Atmospheric HULIS: How humic-like are they? A comprehensive and critical review, Atmos. Chem. Phys., 6, 729-753, doi:10.5194/acp-6-729-2006, 2006.

Hanzlík, P., Jehlicka, J., Weishauptova, Z., and Sebek, O.: Adsorption of copper, cadmium and silver from aqueous solutions onto natural carbonaceous materials, Plant. Soil. Environ., 50, 257 264, 2004.

Helmy, A. K., Ferreiro, E. A., and de Bussetti, S. G.: The surface energy of kaolinite, Colloid. Polym. Sci., 283, 225-228, 2004.

Heymsfield, A. J., Miloshevich, L. M., Twohy, C., Sachse, G., and Oltmans, S.: Upper tropospheric relative humidity observations and implications for cirrus ice nucleation, Geophys. Res. Lett., 25, 1343-1350, 1998.

Hudson, P. K., Murphy, D. M., Cziczo, D. J., Thomson, D. S., de Gouw, J. A., Warneke, C., Holloway, J., Jost, J. R., and Hubler, G.: Biomass-burning particle measurements: characteristic composition and chemical processing, J. Geophys. Res., 109, D23S27, doi:10.1029/2003JD004398, 2004.

Iinuma, Y., Brueggemann, E., Gnauk, T., Mueller, K., Andreae, M. O., Helas, G., Parmar, R., and Herrmann, H.: Source characterization of biomass burning particles: the combustion of selected European conifers, African hardwood, savanna grass, and German and Indonesian peat, J. Geophys. Res., 112, D08209, doi:10.1029/2006JD007120, 2007.

Jost, H. J., Drdla, K., Stohl, A., Pfister, L., Loewenstein, M., Lopez, J. P., Hudson, P. K., Murphy, D. M., Cziczo, D. J., 
Fromm, M., Bui, T. P., Dean-Day, J., Gerbig, C., Mahoney, M. J., Richard, E. C., Spichtinger, N., Pittman, J. V., Weinstock, E. M., Wilson, J. C., and Xueref, I.: In-situ observations of mid-latitude forest fire plumes deep in the stratosphere, Geophys. Res. Lett., 31, L11101, doi:10.1029/2003GL019253, 2004.

Kanji, Z. A., Florea, O., and Abbatt, J. P. D.: Ice formation via deposition nucleation on mineral dust and organics: dependence of onset relative humidity on total particulate surface area, Environ. Res. Lett., 3, 025004, doi:10.1088/1748-9326/3/2/025004, 2008.

Kärcher, B., and Lohmann, U.: A parameterization of cirrus cloud formation: heterogeneous freezing, J. Geophys. Res., 108, 4402, doi:10.1029/2002JD003220, 2003.

Knopf, D. A.: Do NAD and NAT form in liquid stratospheric aerosols by pseudoheterogeneous nucleation?, J. Phys. Chem. A, 110, 5745-5750, 2006.

Knopf, D. A. and Alpert, P. A.: A Water Activity Based Model of Heterogeneous Ice Nucleation Kinetics for Freezing of Water and Aqueous Solution Droplets, Faraday Discuss., doi:10.1039/C3FD00035D, 2013.

Knopf, D. A. and Forrester, S. M.: Freezing of water and aqueous $\mathrm{NaCl}$ droplets coated by organic monolayers as a function of surfactant properties and water activity, J. Phys. Chem. A., 115, 5579-5591, doi:10.1021/jp2014644, 2011.

Knopf, D. A. and Koop, T.: Heterogeneous nucleation of ice on surrogates of mineral dust, J. Geophys. Res., 111, D12201, doi:10.1029/2005JD006894, 2006.

Knopf, D. A. and Lopez, M. D.: Homogeneous ice freezing temperatures and ice nucleation rates of aqueous ammonium sulfate and aqueous levoglucosan particles for relevant atmospheric conditions, Phys. Chem. Chem. Phys., 11, 8056-8068, 2009.

Knopf, D. A. and Rigg, Y. J.: Homogeneous ice nucleation from aqueous inorganic/organic particles representative of biomass burning: water activity, freezing temperatures, nucleation rates, J. Phys. Chem. A, 115, 762-773, doi:10.1021/jp109171g, 2011.

Knopf, D. A., Koop, T., Luo, B. P., Weers, U. G., and Peter, T.: Homogeneous nucleation of NAD and NAT in liquid stratospheric aerosols: insufficient to explain denitrification, Atmos. Chem. Phys., 2, 207-214, doi:10.5194/acp-2-207-2002, 2002.

Knopf, D. A., Wang, B., Laskin, A., Moffet, R. C., and Gilles, M. K.: Heterogeneous nucleation of ice on anthropogenic organic particles collected in Mexico City, J. Geophys. Res., 37, L11803, doi:10.1029/2010GL043362, 2010.

Knopf, D. A., Alpert, P. A., Wang, B., and Aller, J. Y.: Stimulation of ice nucleation by marine diatoms, Nat. Geosci., 4, 88-90, doi:10.1038/NGEO1037, 2011.

Konovalov, I. B., Beekmann, M., D'Anna, B., and George, C.: Significant light induced ozone loss on biomass burning aerosol: evidence from chemistry-transport modeling based on new laboratory studies, Geophys. Res. Lett., 39, L17807, doi:10.1029/2012GL052432, 2012.

Koop, T.: Homogeneous ice nucleation in water and aqueous solutions, Z. Phys. Chemie-Int. J., 218, 1231-1258, 2004.

Koop, T. and Zobrist, B.: Parameterizations for ice nucleation in biological and atmospheric systems, Phys. Chem. Chem. Phys., 11, 10839-10850, 2009

Koop, T., Ng, H. P., Molina, L. T., and Molina, M. J.: A new optical technique to study aerosol phase transitions: the nucleation of ice from $\mathrm{H}_{2} \mathrm{SO}_{4}$ aerosols, J. Phys. Chem. A, 102, 8924-8931, 1998.
Koop, T., Luo, B. P., Tsias, A., and Peter, T.: Water activity as the determinant for homogeneous ice nucleation in aqueous solutions, Nature, 406, 611-614, 2000.

Lee, R. E., Zachariassen, K. E., and Baust, J. G.: Effect of cryoprotectants on the activity of hemolymph nucleating-agents in physical solutions, Cryobiology, 18, 511-514, 1981.

Lee, R. E., Zachariassen, K. E., and Baust, J. G.: Winter survival of an adult bark beetle Acuminatus gyll, J. Insect Physiol., 30, 421-429, 1984.

Lin, P., Engling, G., and Yu, J. Z.: Humic-like substances in fresh emissions of rice straw burning and in ambient aerosols in the Pearl River Delta Region, China, Atmos. Chem. Phys., 10, 64876500, doi:10.5194/acp-10-6487-2010, 2010.

Lohmann, U., Humble, J., Leaitch, W. R., Isaac, G. A., and Gultepe, I.: Simulations of ice clouds during FIRE ACE using the CCCMA single-column model, J. Geophys. Res., 106, 1512315138, doi:10.1029/2000JD900473, 2001.

Lohmann, U., Broekhuizen, K., Leaitch, R., Shantz, N., and Abbatt, J.: How efficient is cloud droplet formation of organic aerosols?, Geophys. Res. Lett., 31, L05108, doi:10.1029/2003GL018999, 2004.

Lukacs, H., Gelencser, A., Hammer, S., Puxbaum, H., Pio, C., Legrand, M., Kasper-Giebl, A., Handler, M., Limbeck, A., Simpson, D., and Preunkert, S.: Seasonal trends and possible sources of brown carbon based on 2-year aerosol measurements at six sites in Europe, J. Geophys. Res., 112, D23S18, doi:10.1029/2006JD008151, 2007.

Lüönd, F., Stetzer, O., Welti, A., and Lohmann, U.: Experimental study on the ice nucleation ability of size-selected kaolinite particles in the immersion mode, J. Geophys. Res., 115, D14201, doi:10.1029/2009JD012959, 2010.

Marcolli, C., Gedamke, S., Peter, T., and Zobrist, B.: Efficiency of immersion mode ice nucleation on surrogates of mineral dust, Atmos. Chem. Phys., 7, 5081-5091, doi:10.5194/acp-7-50812007, 2007.

Mayol-Bracero, O. L., Guyon, P., Graham, B., Roberts, G., Andreae, M. O., Decesari, S., Facchini, M. C., Fuzzi, S., and Artaxo, P.: Water-soluble organic compounds in biomass burning aerosols over Amazonia - 2. Apportionment of the chemical composition and importance of the polyacidic fraction, J. Geophys. Res., 107, 8091, doi:10.1029/2001JD000522, 2002.

McGuire, J. A., Shen, Y. R.: Ultrafast vibrational dynamics at water interfaces, Science, 313, 1945-1948, doi:10.1126/science.1131536, 2006.

Miller, K.: Cold-hardiness strategies of some adult and immature insects overwintering in interior Alaska, Comp. Biochem. Physiol. A, 73, 421-429, 1982.

Morris, C. E., Georgakopoulos, D. G., and Sands, D. C.: Ice nucleation active bacteria and their potential role in precipitation, J. Phys. IV, 121, 87-103, doi:10.1051/jp4:2004121004, 2004.

Mukai, H. and Ambe, Y.: Characterization of a humic acidlike brown substance in airborne particulate matter and tentative identification of its origin, Atmos. Environ., 20, 813-819, doi:10.1016/0004-6981(86)90265-9, 1986.

Murphy, D. M. and Koop, T.: Review of the vapour pressures of ice and supercooled water for atmospheric applications, Q. J. Roy. Meteor. Soc., 131, 1539-1565, 2005.

Murphy, D. M., Thomson, D. S., and Mahoney, T. M. J.: In situ measurements of organics, meteoritic material, mercury, and other 
elements in aerosols at 5 to 19 kilometers, Science, 282, 16641669, 1998.

Murphy, D. M., Cziczo, D. J., Hudson, P. K., and Thomson, D. S.: Carbonaceous material in aerosol particles in the lower stratosphere and tropopause region, J. Geophys. Res., 112, D04203, doi:10.1029/2006JD007297, 2007.

Murray, B. J., Broadley, S. L., Wilson, T. W., Atkinson, J. D., and Wills, R. H.: Heterogeneous freezing of water droplets containing kaolinite particles, Atmos. Chem. Phys., 11, 4191-4207, doi:10.5194/acp-11-4191-2011, 2011.

Pinti, V., Marcolli, C., Zobrist, B., Hoyle, C. R., and Peter, T.: Ice nucleation efficiency of clay minerals in the immersion mode, Atmos. Chem. Phys., 12, 5859-5878, doi:10.5194/acp-12-58592012, 2012.

Pio, C. A., Legrand, M., Alves, C. A., Oliveira, T., Afonso, J., Caseiro, A., Puxbaum, H., Sanchez-Ochoa, A., and Gelencser, A.: Chemical composition of atmospheric aerosols during the 2003 summer intense forest fire period, Atmos. Environ., 42, 75307543, doi:10.1016/j.atmosenv.2008.05.032, 2008.

Prenni, A. J., Demott, P. J., Rogers, D. C., Kreidenweis, S. M., McFarquhar, G. M., Zhang, G., and Poellot, M. R.: Ice nuclei characteristics from M-PACE and their relation to ice formation in clouds, Tellus B, 61, 436-448, 2009.

Pruppacher, H. R. and Klett, J. D.: Microphysics of Clouds and Precipitation, Kluwer Academic Publishers, the Netherlands, 1997.

Rogers, D. C., DeMott, P. J., Kreidenweis, S. M., and Chen, Y. L.: A continuous-flow diffusion chamber for airborne measurements of ice nuclei, J. Atmos. Ocean. Technol., 18, 725-741, 2001.

Salt, R. W.: Role of glycerol in the cold-hardening of Bracon cephi (Gahan), Can. J. Zoo., 37, 59-69, 1959.

Sassen, K. and Dodd, G., C.: Homogeneous nucleation rate for highly supercooled cirrus cloud droplets, J. Atmos. Sci., 45, 1357-1369, 1988.

Schmidl, C., Marr, L. L., Caseiro, A., Kotianova, P., Berner, A., Bauer, H., Kasper-Giebl, A., and Puxbaum, H.: Chemical characterisation of fine particle emissions from wood stove combustion of common woods growing in midEuropean Alpine regions, Atmos. Environ., 42, 126-141, doi:10.1016/j.atmosenv.2007.09.028, 2008.

Seifert, M., Ström, J., Krejci, R., Minikin, A., Petzold, A., Gayet, J.F., Schumann, U., and Ovarlez, J.: In-situ observations of aerosol particles remaining from evaporated cirrus crystals: Comparing clean and polluted air masses, Atmos. Chem. Phys., 3, 10371049, doi:10.5194/acp-3-1037-2003, 2003.

Smith, R. and Kay, B.: The existence of supercooled liquid water at 150 K, Nature, 398, 788-791, 1999.

Tanaka, K.: Measurements of self-diffusion coefficients of water in pure water and in aqueous-electrolyte solutions, J. Chem. Soc. Farad. T. 1, 71, 1127-1131, doi:10.1039/f19757101127, 1975.

Vali, G.: Quantitative evaluation of experimental results on heterogeneous freezing nucleation of supercooled liquids, J. Atmos. Sci., 29, 402-409, 1971.

Verlinde, J., Harrington, J. Y., McFarquhar, G. M., Yannuzzi, V. T., Avramov, A., Greenberg, S., Johnson, N., Zhang, G., Poellot, M. R., Mather, J. H., Turner, D. D., Eloranta, E. W., Zak, B. D., Prenni, A. J., Daniel, J. S., Kok, G. L., Tobin, D. C., Holz, R., Sassen, K., Spangenberg, D., Minnis, P., Tooman, T. P., Ivey, M. D., Richardson, S. J., Bahrmann, C. P., Shupe, M., DeMott, P. J., Heymsfield, A. J., and Schofield, R.: The mixed-phase
Arctic cloud experiment, B. Am. Meteorol. Soc., 42, 248-252, 2007.

Wang, B. and Knopf, D. A.: Heterogeneous ice nucleation on particles composed of humic-like substances impacted by $\mathrm{O}_{3}$, J. Geophys. Res., 116, D03205, doi:10.1029/2010JD014964, 2011.

Wang, B., Lambe, A. T., Massoli, P., Onasch, T. B., Davidovits, P., Worsnop, D. R., and Knopf, D. A.: The deposition ice nucleation and immersion freezing potential of amorphous secondary organic aerosol: pathways for ice and mixed-phase cloud formation, J. Geophys. Res., 117, D16209, doi:10.1029/2012JD018063, 2012a.

Wang, B., Laskin, A., Roedel, T., Gilles, M. K., Moffet, R. C., Tivanski, A. V., and Knopf, D. A.: Heterogeneous ice nucleation and water uptake by field-collected atmospheric particles below $273 \mathrm{~K}$, J. Geophys. Res., 117, D00V19, doi:10.1029/2012JD017446, 2012 b.

Welti, A., Lüönd, F., Kanji, Z. A., Stetzer, O., and Lohmann, U.: Time dependence of immersion freezing: an experimental study on size selected kaolinite particles, Atmos. Chem. Phys., 12, 9893-9907, doi:10.5194/acp-12-9893-2012, 2012.

Westbrook, C. D. and Illingworth, A. J.: The formation of ice in a long-lived supercooled layer cloud, Q. J. R. Meteor. Soc., doi:10.1002/qj.2096, in press, 2013.

Wylie, D., Jackson, D., Menzel, W., and Bates, J.: Trends in global cloud cover in two decades of HIRS observations, J. Climate, 18, 3021-3031, doi:10.1175/JCLI3461.1, 2005.

Young, K. D., Leboeuf, E. J..: Glass transition behavior in a peat humic acid and an aquatic fulvic acid, Environ. Sci. Technol., 34, 21, 4549-4553, 2000.

Zobrist, B., Weers, U., and Koop, T.: Ice nucleation in aqueous solutions of poly[ethylene glycol] with different molar mass, J. Chem. Phys., 118, 10254-10261, 2003.

Zobrist, B., Marcolli, C., Koop, T., Luo, B. P., Murphy, D. M., Lohmann, U., Zardini, A. A., Krieger, U. K., Corti, T., Cziczo, D. J., Fueglistaler, S., Hudson, P. K., Thomson, D. S., and Peter, T.: Oxalic acid as a heterogeneous ice nucleus in the upper troposphere and its indirect aerosol effect, Atmos. Chem. Phys., 6, 3115-3129, doi:10.5194/acp-6-3115-2006, 2006.

Zobrist, B., Koop, T., Luo, B. P., Marcolli, C., and Peter, T.: Heterogeneous ice nucleation rate coefficient of water droplets coated by a nonadecanol monolayer, J. Phys. Chem. A, 111, 2149-2155, 2007.

Zobrist, B., Marcolli, C., Peter, T., and Koop, T.: Heterogeneous ice nucleation in aqueous solutions: the role of water activity, J. Phys. Chem. A, 112, 3965-3975, 2008.

Zuberi, B., Bertram, A., Cassa, C. A., Molina, L. T., and Molina, M. J.: Heterogeneous nucleation of ice in $\left(\mathrm{NH}_{4}\right)_{2} \mathrm{SO}_{4}-$ $\mathrm{H}_{2} \mathrm{O}$ particles with mineral dust immersions, Geophys. Res. Lett., 29, 1504, doi:10.1029/2001GL014289, 2002. 